\title{
WPS3463
}

\section{Employment Regulations through the eyes of employers Do they matter and how do firms respond to them?}

\author{
Gaëlle Pierre and Stefano Scarpetta* \\ World Bank, 1818 H Street NW, Washington, DC 20433
}

\begin{abstract}
In this paper, we present evidence on how employers perceive labor regulations and react when these are perceived to constrain the operation of their firm. The paper draws from harmonized surveys of (up to) 17,000 firms around the world and compares employers' responses with actual labor legislation. We find that employers' concerns about labor regulations are closely matched by the relative stringency of de jure labor laws. Countries that have, from an international perspective, tight labor regulations tend to have higher proportions of employers reporting these regulations as severe constraints. But not all firms are affected in the same way by onerous labor regulations. Medium-size firms are those whose business and prospects for growth are most negatively affected. Similarly, innovating firms are disproportionally affected by tight labor regulations. There is also clear evidence in the data that firms facing tight regulations invest more in training and make greater use of temporary employment. Small firms mainly rely on temporary employment, while medium and large firms, as well as innovating firms, tend to rely more on on-the-job training if labor regulations make hiring and firing very costly.
\end{abstract}

Keywords: employment protection indices, firms surveys, training, temporary employment

JEL classification: J23, J65, K31

* 1119 Corresponding author: Stefano Scarpetta (mailto:Sscarpetta@worldbank.org ; Tel: +1202458 


\section{Introduction}

Economists and policy makers have long debated about the effects of hiring and firing regulations on workers' and firms' behavior. Some form of intervention in this area is clearly justified by the need to protect workers from arbitrary actions and to provide some stability in employment, which can be particularly important in the absence of effective social safety nets. There could also be efficiency considerations to the extent hiring and firing regulations lead to long-lasting work relationships that encourage firms' investment in the human capital of their workforce. But, as with the majority of labor regulations, onerous employment protection provisions can raise labor costs and reduce job creation. Moreover, by raising labor adjustment costs, employment protection may also reduce firms' ability to cope with a rapidly changing global economy and take advantage of the opportunities offered by new technologies and access to new markets. When labor demand is reduced by onerous employment protection, vulnerable groups in the labor market - including women, youths and the low skilled - generally bear most of the brunt, with higher unemployment and weaker access to formal jobs.

The theoretical and empirical literature on employment protection regulations has grown rapidly in the past decade (see the recent reviews by Addison and Teixeira, 2003; Heckman and Pagès, 2004; Young, 2003; OECD, 2004). Most theoretical models are in concordance with the idea that, by raising labor adjustment costs, employment protection reduces labor mobility. But there is no consensus as to whether reduced mobility should lead to weaker labor market outcomes in terms of employment or unemployment rates.

As theoretical models have different predictions about the aggregate effects of employment protection on the labor market, the issue becomes essentially an empirical one. However, empirical analyses have so far provided varying results. Indeed, since the seminal contribution of Lazear in 1990, a large number of studies have studied the impact of employment protection on labor market outcomes using different country samples, indicators of regulation and empirical approaches.

One populated strand of this empirical literature - Lazear (1990), followed by Grubb and Wells (1993) and updated by the OECD (1998 and 2004) - attempts to summarize basic aspects of the employment protection legislation (EPL) into cardinal indicators. Lazear largely focuses on severance payment provisions and periods of notice required before employment termination, while subsequent work extends the coverage of the EPL indicators to include the complexity and opacity of procedures for individual and collective dismissals and regulations affecting atypical job contracts (fixed-term contracts and contracts through temporary work agencies). The World Bank has recently extended the coverage of these indicators to about 140 countries (Djankov et al. 2003). These synthetic indicators have clear advantages. They code existing regulations using a common transparent procedure, thereby enabling cross-country comparisons. At the same time, however, the construction of these EPL indicators suffers from problems of subjectivity in the interpretation of legislation, difficulties in aggregating different components of the legislation that may have a different impact on firms' decisions and, most importantly, difficulties in attributing scores to legal provisions that may be applied

differently in practice (Bertola et al. 2000). This latter point is of particular importance 
because countries differ in the degree of enforcement of labor regulations, and other -- often informal - rules may be more important than those written in the labor codes.

An alternative approach to gauge the stringency of labor regulations is to rely on surveys of employers (e.g. Freeman, 2001; Di Tella and and MacCulloch, forthcoming). Business people presumably should know what aspects of labor laws actually affect business conditions as well as wages and employment. This approach is not without problems either. The questions raised in the surveys concerning labor regulation are often fairly vague and subject to different interpretations. Managers respond very differently depending on whether their company faces good or bad times even if underlying labor laws have not changed. Even more important, business perceptions are rooted in the country's environment in which firms operate: what firms perceive as a constraining regulation in their own country may still be fairly liberal from an international perspective. Cross-country comparisons may therefore be difficult using business perceptions of labor regulations.

In this paper we bring together two novel sets of data from these two strands of empirical literature. The first draws from a review of legislation in different areas, including labor, for about 140 countries around the world in the late 1990s (World Bank, Doing Business Database, 2004a). These data allow the construction of synthetic indicators of the stringency of employment protection, summarizing different interrelated aspects of the legislation, such as notice period, severance payments, length of temporary contracts, etc. These synthetic indicators pass simple validation tests: for example they correlate well with other synthetic indicators produced by the OECD for its member countries, arguably the most complete measures available. The second set of data draws from two separate surveys of employers conducted by the World Bank in the past few years. The World Bank Business Environment survey (WBES) covers firms in more than 80 countries, but the sample in each country is fairly small and information on firms' characteristics is limited. A more recent survey - the World Bank Investment Climate survey -- so far covers fewer countries (about 50) but many more firms in each country. This survey also allows for better control for firm characteristics and behavior.

With these data we address three main questions.

- Do employers in countries with relatively more stringent employment protection regulation tend to report these regulations as more constraining for their operation and growth plans?

- Which firms are more likely to report labor regulations as particularly constraining for their operation?

- Finally, how do firms react to constraining labor regulations? For example, do they hire more temporary workers to circumvent rigid rules for regular workers? Do they invest more in training to enable their existing workforce to adjust to new technologies, instead of changing the skill composition of the workforce by hiring and firing workers? 
To anticipate our results we found that, despite weak enforcement in some countries, employment protection legislation does matter for employers in their decision to invest and expand. Indeed, countries with relatively more stringent EPL tend to be those where employers report more severe constraints from this legislation for their operations and potentials for expansion. Moreover, in countries where employment protection is relatively strict, firms make greater use of training to accommodate the workforce to the needs of new technologies, but also use more temporary contracts to enhance labor flexibility.

The paper is organized as follows. In Section 2 we review the theoretical links between employment protection and different labor market outcomes and summarize the main findings of the empirical literature. In Section 3 we present the data used in our empirical analysis. Section 4 presents the empirical results on the links between employers' perceptions and actual regulations, and on their behavioral responses to these regulations. Section 5 details our results and Section 6 concludes.

\section{Why does EPL matter for employment and labor market flows?}

Most countries have laws and regulations governing the employment relationship between workers and firms. These may be written in labor codes, current legislations and norms set by collective agreements. Within these rules and regulations, those focusing on the hiring and firing of workers are often referred to as "employment protection" legislations (EPL). They govern unfair dismissals, restrictions on lay-offs for economic reasons, compulsory severance payments, minimum notice periods and administrative authorizations, and terms and lengths of fixed-term contracts and the operation of temporary work agencies (TWA).

\section{Theory}

The EPL regulations may affect the equilibrium level of employment -- as well as its dynamics over the business cycle -- in different ways. By reinforcing job security, EPL may enhance productivity performance, as workers will be more willing to co-operate with employers in the development of the production process (Akerlof, 1984). To the extent that EPL leads to long-lasting work relationships, it may encourage employers to provide training to workers with potentially beneficial effects on human capital and labor productivity. A better skilled workforce may also increase internal flexibility and thus lead to a better functioning of production activity (Piore, 1986). EPL may also be a way to internalize the social costs of dismissals by moving the social burden of re-allocating a worker to another job closer to the firm's profitability criteria (Lindbeck and Snower, 1988).

However, if EPL is very strict, firms may become more cautious about adjusting their workforce with the ultimate effect of reducing labor turnover, i.e. movements from employment to unemployment and from unemployment back to employment (Bertola, 1992). Lazear (1990) suggests that this may not have an impact on labor demand if firing costs imposed on firms are compensated by reverse transfer from the worker to the firm without influencing labor demand. But even if the cost of EPL cannot be fully shifted to 
workers, labor demand may not decline because firms subject to positive shocks will hire less workers than otherwise, but also firms with negative shocks will be less prone to firing (Bertola, 1990, Bentolila and Bertola, 1990).

EPL may, however, have other effects on aggregate labor demand. By raising labor adjustment costs, EPL may slow down the reallocation of resources from declining industries to growing industries and may have negative implications for economic and labor market outcomes. Hopenhayn and Rogerson (1993) study a general equilibrium model with entry and exit of firms and show that a tax on job destruction can reduce employment rate significantly. However, Alvarez and Varacierto (1998), using an extended version of the Hopenhayn and Rogerson model with frictions in a world of imperfect insurance markets, show that severance payments may be welfare improving the reduction in firms' layoffs and stronger search efforts by the unemployed reduce unemployment enough to compensate for lower consumption levels due to higher costs for firms.

A different degree of strictness of regulation governing regular versus temporary employment (fixed-term contracts and contracts through temporary work agencies) may affect the structure of employment. Stricter regulations for regular contracts relative to those for temporary contracts are likely to promote a shift from regular to temporary employment (as it is occurring in a number of European countries). This has the potential effect of distorting the optimal composition of employment between temporary and regular contracts. Moreover, those who are able to maintain a regular contract (often the insiders) will enjoy an even higher level of job security, bringing about an increase in wage pressure (Bentolila and Dolado, 1994). In contrast, those under temporary contracts (often youths and other workers with little work experience or low skills) will bear the brunt of employment adjustment (Saint Paul, 1996).

Employment protection legislations are also likely to interact with other policies in the labor market. Bertola and Rogerson (1997) suggest that similar labor market flows can be associated with very different employment protection legislation if the welfare state cushion the costs of unemployment. Boeri and Burda (2004) suggest that the presence of high firing costs may reinforce the preference for rigid wage regimes: firing costs compound renegotiation costs in their model, further increasing the utility of rigid wage for workers who keep their jobs. 


\section{The empirical evidence}

Empirical evidence on the impact of employment protection legislation is mixed, not least because of the lack of suitable data on the enforcement and evolutions of regulations over time (Bertola et al., 2000). A clear distinction exists between the potential effects of EPL on employment turnover and on the equilibrium level of employment (unemployment) and its composition (temporary/regular; youths/prime-age workers etc.).

Employment turnover. There is consistent empirical evidence that strict employment protection legislation reduces unemployment turnover. Under strict EPL provisions, the unemployment pool is more stagnant, with fewer people being laid off, but also fewer unemployed people getting a new job (see, e.g. Bentolila and Bertola, 1990; and Nickell and Layard, 1998). The effects on employment turnover are less clear cut: Bertola and Rogerson (1997) and Boeri (1999) found similar job creation and job destruction rates across countries with different EPL regimes. A possible explanation of the contrasting results for unemployment and employment flows is that strict EPL may foster job-to-job shifts rather than overall employment turnover insofar as employers and workers seek direct shifts from one job to another without intervening unemployment spells, in order to avoid the associated dismissal and search costs.

The level of employment. Some studies (e.g. Scarpetta, 1996; Nickell 1997; Di Tella and MacCulloch, forthcoming; Nicoletti and Scarpetta, 2004) suggest a detrimental effect of strict EPL on the level of employment to working-age population ratios. Nickell and Layard (1999) indicate that this may be partially due to the low participation rates in Southern European countries, which also have strict EPL. However, participation rates may be low, especially amongst the youths, precisely because employment prospects are lower the stricter the EPL system. ${ }^{1}$

Overall unemployment rate. There is also no consensus as to the overall impact of EPL on unemployment. Part of the disagreement stems from the use of different models. However, disagreement persists even amongst papers using similar indicators (the OECD summary index, see OECD 1999).

Interactions between EPL and other institutions or shocks. The effects of EPL on unemployment (or employment) are stronger when accounting for potential interactions between EPL and other institutions. In particular, Elmeskov et al. (1998), Belot and van Ours (2000) and Nicoletti and Scarpetta (2004) suggest that stringent employment protection tend to increase structural unemployment (or reduce employment) in countries where the higher labor costs associated to employment protection are not transferred onto

1 Recent papers have analyzed the impact of EPL reform in individual countries, or states within a country. For example, the EPL reforms in Colombia (Kugler, 2004) and Peru (Saavedra and Torero, 2004) in the 1990s led to a higher response of employment to output growth, with speedier employment adjustment but also positive employment effects. In Colombia, the reform has also contributed to increased compliance with labor legislation by lowering the costs of formal production. Besley and Burgess (2004)

found that amendments to the strict employment regulation in Andra Pradesh, one Indian state, in the 1980s contributed to raise significantly employment and growth in the next decade. However, other studies examining labor reforms in Chile and Brazil found no evidence of statistically significant effects on employment. See Pages and Montenegro (1999) for Chile and P. De Barros and Conseuil (2004) for Brazil. 
lower wages. Strong bargaining power of workers and lack of coordination amongst workers' representatives often lead to lower wage flexibility reinforcing the effect of stringent EPL on labor market outcomes.

Other studies have hypothesized that employment protection, as well as other policy and institutional factors in the labor market, may affect unemployment primarily by magnifying the impact of exogenous shocks (Blanchard and Wolfers, 2000). However, Nickell et al. $(2001,2003)$ find that unemployment in OECD countries are mainly due to changes in labor market policy and institutions with no effect stemming from interactions between institutions and shocks.

Composition of employment and unemployment. There is greater consensus in the empirical literature about the unequal effects of stringent EPL on various demographic groups. While EPL is generally shown to have little or no effect on the employment prospect of prime-age men, several studies point to larger negative effects on the employment rates of youth and women. ${ }^{2}$ Moreover, Grubb and Wells (1993) indicated that strict EPL for regular workers may encourage firms to shift to temporary workers and more generally foster self-employment.

But the jurisprudence matters a lot. Employment protection legislation are also subject to courts interpretations, leading to an additional source of variation in the de facto strictness of EPL across countries and over time. Ichino et al. (2003) and Bertola et al. (2000) suggest that jurisprudence may be affected by the underlying labor market conditions; for instance there is evidence that judges' decisions tend to be particularly favorable to workers when unemployment is high. Moreover, compensations for unfair dismissals can deviate largely from the minima set out by legislation because judges may account in their final decision for damages corresponding to past and future financial losses and psychological damages. There are also large differences in the number of cases brought to labor courts, the percentage of cases won by workers and the length of the legal procedure. ${ }^{3}$

The role of jurisprudence in influencing the effect of EPL on the labor market is even more marked in developing and transition countries. In Sri Lanka the government decides the amount of compensation for laid-off workers and has the authority to reject employer demands. The time needed for processing the request for a layoff can be highly unpredictable, taking six months on average, but much more if the procedure involves hearings where employers explain their financial performance and business plans to the government to justify the layoff. In Russia, before the reform of the labor code, trade

2 Nickell and Layard (1998), Scarpetta (1996) and OECD (1999) suggest a stronger effect of strict EPL on youth unemployment. Di Tella and MacCulloch (forthcoming) for OECD countries, and Heckman and Pages (2004) for Latin American countries suggest a negative effect of strict EPL on female employment.

3 For example, while only about 1 per cent of total layoffs end up in court in Australia where 90 percent of the cases are resolved by conciliation, more than 20 percent of layoffs end up in court in France and Germany and, in the former, 75 percent of these cases are won by workers (see OECD, 2004).

Moreover, while on average it takes only a few months for courts to decide on a labor dispute in the United Kingdom, the US, New Zealand and Germany, it takes more than one year in France and in Italy. 
unions had veto power over dismissals for staff reductions or for employees not suited to the job (See World Bank (2003)). Before the 1999 reform in Brazil, representatives of employers and workers sat on the jury of labor courts, a practice that often led to protracted procedures and difficulties in reaching compromise. Because of the complexity of the severance pay schemes, more than 6 percent of all salaried workers (about 2 million) usually filed a lawsuit every year and the average labor dispute took almost three years. The reform restricted the jury to professional lawyers and cut the time to resolve a dispute by half (World Bank, 2002).

\section{How employers react to employment protection}

The effects of EPL on firms' behavior are likely to be mediated by several factors. As discussed above, stringent EPL would not constrain firm performance and job creation if workers fully valued the benefits of employment protection and were willing to trade them off for greater effort or a lower monetary compensation. ${ }^{4}$ But if the costs associated with stringent EPL are too high to be fully transferred into lower wages or higher productivity, or if workers' organization resist wage reductions, then they may lead to lower job creation and possibly lower investment in new technologies.

Temporary versus regular workers. When employment protection legislation is less stringent than legislation for regular workers, firms may be encouraged to hire more workers on a temporary basis to increase workforce flexibility. Indeed many countries around the world have liberalized temporary contracts in the past decade - expanding the list of jobs allowed under temporary contracts, lengthening their maximum duration and/or allowing temporary work agencies to operate. Evidence from France, Spain, Argentina, Peru, and Colombia suggests that the asymmetric liberalization of temporary contracts, while leaving in place strict regulations for regular contracts, has led to significant shifts of labor demand in favor of temporary employment. In Spain temporary employment reached almost one-third of the total workforce after the reform of temporary contracts in the mid-1980s. In Peru, the liberalization of temporary employment in the early 1990s led to an increase in temporary employment from 20 percent in 1990 to 55 percent in 2000. In Colombia there was a similar large increase and in South Africa more than 90 percent of large firms are reported to make greater use of temporary workers to increase flexibility of the workforce. Interestingly, while about one-third of formal micro-enterprises in South Africa use temporary employment, the share is less than 10 percent among informal firms (Chandra and others, 2001).

Liberalizing temporary contracts, while leaving in place strict regulations on regular contracts tends to reinforce the inequality in the labor market (see OECD, 2004). Firms will have stronger incentives to hire more workers at the entry level and employ them for a limited period, without giving them a regular position thereafter. This increases job turnover but not necessarily overall employment or productivity, because the additional hires will be accompanied by additional layoffs at the end of the temporary contracts, and

$4 \quad$ Labor protection provisions can be justified on the grounds that workers are risk averse and that they do not have the possibility to privately insure themselves against labor market uncertainty or prefer to trade off lower earnings for better working conditions. See Bertola (2004). 
there will be little or no development of internal human capital. In Argentina and Spain the liberalization of temporary employment was partially reversed after a few years because of the large expansion of temporary employment and, in Spain, net job creation has really picked up only after the government reformed regular contracts in the mid1990s. ${ }^{5}$

The size of firms. Stringent EPL is also likely to influence firms differently depending on their characteristics. Evidence suggests that stringent EPL is associated with larger proportions of self-employed, informal firms, and small firms. ${ }^{6}$ Indeed, firms facing high labor adjustment constraints may either remain small - and more or less informal in developing countries or exempt from employment regulations in several industrial countries - or move to a higher scale, at which hiring and firing costs play a smaller role in total expected adjustment costs. In many developing and transition economies, larger firms are also able to obtain special treatment from local or national authorities to circumvent rigid rules. ${ }^{7}$

Greater use of training. Firms facing high labor adjustment costs may make greater use of training to adapt the workforce to the needs of new technologies (see e.g. Cappelli, 2000). Training may be a valid alternative to hiring and firing only under certain conditions. In particular, when employment protection is strict and wages are fairly compressed, training may be a valid option to upgrade the skills of the workforce because there is a greater wedge between productivity and wages at high skill levels. ${ }^{8}$ The combination of wage compression and high labor adjustment costs - which is common in many countries -- tend to favor a process of competence accumulation based on firmsupported training and on-the-job learning. In this context, training may compensate for the negative effect that labor regulations may have on the optimal allocation of workers (as illustrated in the case of Germany in Acemoglu and Pischke, 1998). In addition, firms may use training to make sure workers have adequate skills to be able to adopt flexible work practices $^{9}$ (Gittleman et al., 1998). In turn, internal flexibility is a strategy which can be a substitute as well as a complement to a strategy of involuntary turnover within firms (Cappelli and Neumark, 2001).

$5 \quad$ See Blanchard and Landier (2001) for France; Hopenhayn (2004) for Argentina, Dolado, García-Serrano, and Jimeno (2001) for Spain, Saavedra and Torero (2004) for Peru and Kugler (2004) for Colombia.

$6 \quad$ See Nicoletti and others (2001) on self-employment; Nicoletti and others (2001) for the evidence on firm size; and Scarpetta and others (2002) for the evidence on size of entrant firms and post-entry expansion.

In Russia many large firms have circumvented strict regulations by encouraging workers to leave the firm voluntarily, through wage arrears, prolonged administrative leaves, reduced hours, and other forms of deteriorating working conditions. With no future in the firm and no source of income, many workers eventually quit (World Bank, 2003).

$8 \quad$ Lynch (1994), Blinder and Krueger (1996) and Acemoglu and Pischke (1999) offer some evidence of more firm-sponsored training in more coordinated countries.

$9 \quad$ Flexible work practices include movement away from hierarchical management structures e.g. through improving workers' input into managerial decisions, workers' coordination through occupational lines, etc. (see Gittleman et al., 1998). 


\section{The data}

Our empirical analysis relies on three different datasets. Our de jure indicators of employment protection legislation are drawn from the World Bank Doing Business Database, which provides detailed information on the labor legislation in more than 140 countries around the world. Information on employers' perceptions on labor regulations and on they responses is drawn from two large surveys - the World Bank Business Environment surveys and the Investment Climate surveys.

\section{Measuring the stringency of employment protection legislation}

We focus on two separate aspects of employment protection legislation: that concerning regular contracts and that pertaining to temporary contracts. ${ }^{10}$

\section{Regulation of regular employment}

Drawing from the Doing business database of the World Bank, we focus on the following variables to characterize individual protection against dismissal for workers with regular contracts:

- Procedural requirements. They refer to the process that has to be followed from the decision to lay off a worker to the actual termination of the contract. They include: 1) the grounds for dismissal -- whether it is unfair to terminate the employment contract without cause; whether there is a list of "fair" grounds for dismissal; and whether redundancy is considered a "fair" ground for dismissal; 2) the delay before the notice of dismissal can start (for example, because there has to be a series of previous warnings); 3 ) whether a third party must be notified or consulted; and whether dismissal cannot proceed without the approval of a third party; 4) whether the law mandates retraining or replacement prior of dismissal; 5) whether there are priority rules to dismissal or layoffs; 6) and whether there are priority rules applying to re-employment.

- Notice period required by law for the dismissal of one redundant worker in manufacturing with twenty years of tenure.

- Severance payment (including mandatory indemnity) for the dismissal of one redundant worker in manufacturing with twenty years of tenure.

10 In the Doing Business database, EPL regulations are defined on the basis of a representative worker. The work has the following characteristics: (i) he is a non-executive full-time employee who has been working in the same firm for 20 years; (ii) his salary plus benefits equal the country's GNP per worker during the entire period of employment; (iii) he has a non-working wife and two children, and the family has always resided in the country's most populous city. The employer has the following characteristics: (i) it is a manufacturing company wholly owned by nationals; (ii) its legal domicile and its main place of business is the country's most populous city; (iii) it has 250 workers; and (iv) it abides by every law and regulation, but does not grant workers more prerogatives than are legally mandated. See World Bank (2004c) from more details and http://rru.worldbank.org/DoingBusiness/. 


\section{Regulation of temporary employment}

Indicators of the stringency of EPL for temporary contracts refer to: 1) the "objective" reasons under which they could be offered - only for temporary jobs such as temporary vacancies to replace a regular worker; training contracts, seasonal work; 2) the maximum cumulated duration of a contract.

Detailed indicators for the different components of employment protection have been first normalized from 0 to 1 from the least to the most restrictive in the country sample. They have then been aggregated into two synthetic indicators for regular and temporary contracts and an overall indicator of EPL. The aggregation process follows previous studies (e.g. OECD, 1994, 1999, 2004) and is largely based on simple averages of detailed regulatory aspects (see Annex 1 for details). Table 1 presents the synthetic indicators for all the countries in the sample used in our empirical analysis. As a simple validation test, our two synthetic indicators are highly correlated with those recently produced by the OECD (2004). ${ }^{11}$

Three main points emerge from the synthetic indicators in Table 1. First, there is a large heterogeneity of regulatory settings within each of the world regions. Whether in the industrial country group or any other region, countries differ significantly in the stringency of their labor regulations. Secondly and bearing in mind this within-group variance, some regions tend to have a larger concentration of countries with strict regulations, in particular Europe and Central Asia, South Asia and Latin America. Third, many low-income countries have labor regulations that mimic or even exceed those of industrial economies - even if the latter have approached these conditions only gradually during their process of development. Indeed, while one might have expected a positive relation between the level of mandated labor protection and income across countries (i.e. labor protection is a normal good), the relationship is in fact weakly negative across our sample of countries.

Table 1 The synthetic indicators of the stringency of employment protection for regular and temporary employment

\begin{tabular}{lcccccc}
\hline Country (by region) & $\begin{array}{c}\text { Overall } \\
\text { employment } \\
\text { index }\end{array}$ & Rank & $\begin{array}{c}\text { Regular } \\
\text { employment } \\
\text { protection index }\end{array}$ & $\begin{array}{c}\text { Rank } \\
\text { employment } \\
\text { index }\end{array}$ \\
\hline Sub-Saharan Africa (SAS) & & & & & & \\
Botswana & 0.20 & 24 & 0.40 & 44 & 0 & 1 \\
Cameroon & 0.67 & 75 & 0.67 & 80 & 0.67 & 60 \\
Cote d'Ivoire & 0.53 & 55 & 0.22 & 12 & 0.83 & 70 \\
Ethiopia & 0.57 & 63 & 0.40 & 44 & 0.75 & 63 \\
Ghana & 0.18 & 17 & 0.35 & 31 & 0 & 1 \\
\hline
\end{tabular}

11 In order to check the quality of our index, we compare it to the new indicator derived by the OECD (2004). The comparison can be made for 15 industrial and transition countries: Canada, Czech Republic, France, Germany, Hungary, Italy, Mexico, Poland, Portugal, Slovak Republic, Spain, Sweden, Turkey, United Kingdom, and United States. The correlation between our weighted index for overall employment regulation with the relevant overall OECD index is statistically significant at 1 per cent level (correlation coefficient $=0.82$ ). 


\begin{tabular}{|c|c|c|c|c|c|c|}
\hline Kenya & 0.19 & 19 & 0.38 & 39 & 0 & 1 \\
\hline Madagascar & 0.19 & 19 & 0.22 & 12 & 0.17 & 31 \\
\hline Malawi & 0.20 & 24 & 0.41 & 47 & 0 & 1 \\
\hline Namibia & 0.21 & 27 & 0.41 & 47 & 0 & 1 \\
\hline Nigeria & 0.15 & 11 & 0.30 & 23 & 0 & 1 \\
\hline Senegal & 0.55 & 60 & 0.43 & 53 & 0.67 & 60 \\
\hline South Africa & 0.41 & 43 & 0.33 & 30 & 0.5 & 40 \\
\hline Tanzania & 0.47 & 46 & 0.44 & 56 & 0.5 & 40 \\
\hline Uganda & 0.08 & 4 & 0.15 & 4 & 0 & 1 \\
\hline Zambia & 0.23 & 29 & 0.46 & 59 & 0 & 1 \\
\hline Zimbabwe & 0.14 & 9 & 0.28 & 20 & 0 & 1 \\
\hline \multicolumn{7}{|c|}{ East Asia and the Pacific (EAP) } \\
\hline Cambodia & 0.20 & 24 & 0.39 & 42 & 0 & 1 \\
\hline China & 0.29 & 31 & 0.57 & 72 & 0 & 1 \\
\hline Indonesia & 0.58 & 67 & 0.41 & 47 & 0.75 & 63 \\
\hline Malaysia & 0.15 & 11 & 0.30 & 23 & 0 & 1 \\
\hline Philippines & 0.16 & 13 & 0.32 & 27 & 0 & 1 \\
\hline Singapore & 0.05 & 1 & 0.11 & 1 & 0 & 1 \\
\hline Thailand & 0.57 & 63 & 0.30 & 23 & 0.83 & 70 \\
\hline \multicolumn{7}{|c|}{$\begin{array}{l}\text { Eastern Europe and Central Asia } \\
\text { (ECA) }\end{array}$} \\
\hline Albania & 0.17 & 16 & 0.35 & 31 & 0 & 1 \\
\hline Armenia & 0.37 & 39 & 0.49 & 64 & 0.25 & 32 \\
\hline Azerbaijan & 0.53 & 55 & 0.47 & 61 & 0.58 & 50 \\
\hline Belarus & 0.50 & 51 & 0.41 & 47 & 0.58 & 50 \\
\hline Bosnia and Herzegovina & 0.59 & 69 & 0.35 & 31 & 0.83 & 70 \\
\hline Bulgaria & 0.34 & 35 & 0.17 & 5 & 0.5 & 40 \\
\hline Croatia & 0.67 & 75 & 0.60 & 77 & 0.75 & 63 \\
\hline Czech Republic & 0.30 & 32 & 0.27 & 19 & 0.33 & 38 \\
\hline Estonia & 0.19 & 19 & 0.39 & 42 & 0 & 1 \\
\hline Georgia & 0.37 & 39 & 0.50 & 66 & 0.25 & 32 \\
\hline Hungary & 0.19 & 19 & 0.29 & 21 & 0.08 & 28 \\
\hline Kazakhstan & 0.11 & 7 & 0.22 & 12 & 0 & 1 \\
\hline Kyrgyz Republic & 0.50 & 51 & 0.41 & 47 & 0.58 & 50 \\
\hline Latvia & 0.66 & 73 & 0.49 & 64 & 0.83 & 70 \\
\hline Lithuania & 0.47 & 46 & 0.36 & 37 & 0.58 & 50 \\
\hline Macedonia, FYR & 0.48 & 48 & 0.46 & 59 & 0.5 & 40 \\
\hline Moldova & 0.54 & 57 & 0.50 & 66 & 0.58 & 50 \\
\hline Poland & 0.18 & 17 & 0.35 & 31 & 0 & 1 \\
\hline Romania & 0.79 & 83 & 0.70 & 81 & 0.88 & 76 \\
\hline Russian Federation & 0.16 & 13 & 0.24 & 16 & 0.08 & 28 \\
\hline Serbia and Montenegro & 0.33 & 34 & 0.40 & 44 & 0.25 & 32 \\
\hline Slovak Republic & 0.13 & 8 & 0.18 & 6 & 0.08 & 28 \\
\hline Slovenia & 0.42 & 44 & 0.59 & 76 & 0.25 & 32 \\
\hline Turkey & 0.42 & 44 & 0.35 & 31 & 0.5 & 40 \\
\hline Ukraine & 0.67 & 75 & 0.76 & 83 & 0.58 & 50 \\
\hline Uzbekistan & 0.54 & 57 & 0.50 & 66 & 0.58 & 50 \\
\hline
\end{tabular}




\begin{tabular}{|c|c|c|c|c|c|c|}
\hline \multicolumn{7}{|l|}{ Industrial Countries } \\
\hline Canada & 0.09 & 5 & 0.18 & 6 & 0 & 1 \\
\hline France & 0.66 & 73 & 0.44 & 56 & 0.88 & 76 \\
\hline Germany & 0.56 & 61 & 0.63 & 79 & 0.5 & 40 \\
\hline Italy & 0.57 & 63 & 0.38 & 39 & 0.75 & 63 \\
\hline Portugal & 0.60 & 70 & 0.70 & 81 & 0.5 & 40 \\
\hline Spain & 0.62 & 71 & 0.32 & 27 & 0.92 & 78 \\
\hline Sweden & 0.36 & 38 & 0.48 & 63 & 0.25 & 32 \\
\hline United Kingdom & 0.09 & 5 & 0.19 & 8 & 0 & 1 \\
\hline United States & 0.07 & 2 & 0.13 & 2 & 0 & 1 \\
\hline \multicolumn{7}{|l|}{$\begin{array}{l}\text { Latin America and the Caribbean } \\
(L A C)\end{array}$} \\
\hline Argentina & 0.51 & 53 & 0.43 & 53 & 0.58 & 50 \\
\hline Bolivia & 0.56 & 61 & 0.37 & 38 & 0.75 & 63 \\
\hline Brazil & 0.68 & 79 & 0.52 & 70 & 0.83 & 70 \\
\hline Chile & 0.28 & 30 & 0.31 & 26 & 0.25 & 32 \\
\hline Colombia & 0.48 & 48 & 0.21 & 11 & 0.75 & 63 \\
\hline Costa Rica & 0.35 & 36 & 0.19 & 8 & 0.5 & 40 \\
\hline Dominican Republic & 0.22 & 28 & 0.44 & 56 & 0 & 1 \\
\hline Ecuador & 0.37 & 39 & 0.41 & 47 & 0.33 & 38 \\
\hline El Salvador & 0.67 & 75 & 0.43 & 53 & 0.92 & 78 \\
\hline Guatemala & 0.49 & 50 & 0.24 & 16 & 0.75 & 63 \\
\hline Haiti & 0.14 & 9 & 0.29 & 21 & 0 & 1 \\
\hline Honduras & 0.07 & 2 & 0.13 & 2 & 0 & 1 \\
\hline Mexico & 0.74 & 81 & 0.57 & 72 & 0.92 & 78 \\
\hline Nicaragua & 0.16 & 13 & 0.32 & 27 & 0 & 1 \\
\hline Panama & 0.73 & 80 & 0.53 & 71 & 0.92 & 78 \\
\hline Peru & 0.58 & 67 & 0.57 & 72 & 0.58 & 50 \\
\hline Uruguay & 0.35 & 36 & 0.20 & 10 & 0.5 & 40 \\
\hline $\begin{array}{l}\text { Venezuela, RB } \\
\text { Middle East and North Africa } \\
\text { (MENA) }\end{array}$ & 0.54 & 57 & 0.25 & 18 & 0.83 & 70 \\
\hline Algeria & 0.40 & 42 & 0.22 & 12 & 0.58 & 50 \\
\hline Egypt, Arab Rep. & 0.31 & 33 & 0.62 & 78 & 0 & 1 \\
\hline Tunisia & 0.57 & 63 & 0.47 & 61 & 0.67 & 60 \\
\hline \multicolumn{7}{|l|}{ South Asia } \\
\hline Bangladesh & 0.19 & 19 & 0.38 & 39 & 0 & 1 \\
\hline Bhutan & 0.63 & 72 & 0.35 & 31 & 0.92 & 78 \\
\hline India & 0.51 & 53 & 0.51 & 69 & 0.5 & 40 \\
\hline Pakistan & 0.75 & 82 & 0.57 & 72 & 0.94 & 83 \\
\hline
\end{tabular}

See Annex 1 for an explanation of the construction of these indexes.

\section{Employers' perception of the stringency of employment protection legislation}

Micro level data on firm characteristics, employers' perception about labor regulations and their behavior are drawn from two separate business establishment surveys. The World Business Environment Survey (WBES, World Bank 2000) contains a large 
number of countries but a relatively small sample of firm in each country, while the Investment Climate Survey (ICS) has a relatively smaller country sample but covers many more firms in each country (see below). These two datasets complete each other for our purpose: the WBES enables us to see whether the simple relation between perceptions and de jure labor regulations is consistent across a large number of developing, transition and industrial countries. The ICS, on the other hand, provides information that enables us to carry out a deeper analysis of the reaction of firms to labor regulations.

\section{World Business Environment Survey}

The World Business Environment Survey (WBES 2000) is a survey of over 10,000 firms in 81 countries that examines a wide range of interactions between firms and the State. Based on face-to-face interviews with firm managers and owners in late 1999 and early 2000, the WBES generated measurements in such areas as corruption, judiciary, lobbying and the quality of the business environment. ${ }^{12}$

The main variable of interest in our analysis is the perception that respondents have of labor regulations. In the WBES this is measured through the following question: "Please judge on a four point scale ${ }^{13}$ how problematic are these different regulatory areas for the operation and growth of your business (Please do not select more than 4 obstacles as the "major")". In addition to labor regulations, seven other regulatory aspects are proposed: business licensing, customs/foreign trade regulation, foreign currency/exchange regulations, environmental regulations, fire/safety regulations, tax regulations/administration, and high taxes.

Through targeted selection and replacement, at least 100 surveys of private firms having representative characteristics were completed. In general, these characteristics include the following: (i) Sector: In each country, the sectoral composition in terms of manufacturing (including agro-processing) versus services (including commerce) is determined by relative contribution to GDP, subject to a $15 \%$ minimum for each category; (ii) Size: At least $15 \%$ of the sample are small firms and $15 \%$ are large firms; (iii) Ownership: At least 15\% of the firms have foreign control. (iv) Exporters: At least $15 \%$ of firms are exporters, meaning that some significant share of their output is exported. (v) Location: At least $15 \%$ of firms are in the category "small city or countryside".

12 The surveys were carried out following the same terms of reference in all countries. The questionnaire was translated as required for each of the countries. It was pre-tested with at least five enterprises in each country to assure its appropriateness, adjusting translated phrases to make the survey more understandable. The questionnaire was then revised and codified as indicated by pre-testing and analysis. A sample frame of private businesses as complete as possible was developed in each country and from each a sample of at least 100 firms meeting the distributional criteria approved by the client was selected (World Bank, 2000).

13 Where 1 = no obstacle, $2=$ minor obstacle, $3=$ moderate obstacle, $4=$ major obstacle. 
Additional useful variables include (among others): (i) ownership: public ownership refers to whether the firm is at least partly owned by the government; (ii) Employment expansion: full-time employment increased in the previous three years.

\section{Investment Climate Survey}

The Investment Climate Survey (ICS) has so far been carried out in 51 developing and transition economies. The aim of this survey is to provide quantitative data on investment climate which are comparable at the international and regional levels. The survey is normally carried out under the auspices of national stakeholders, which could be an employers association as in the case of India, a development research institution as in the case of China and Ethiopia, an indigenous development agency as in the case of Morocco and Pakistan, or the central statistical bureau as was the case in Bolivia.

Because the priorities of these surveys vary across countries, ICS are not all exactly the same. However, in order to make these as comparable as possible, a set of criteria were defined: (i) the survey sampling unit is the establishment; ${ }^{14}$ (ii) interviews are carried out face to face by trained enumerators with establishments' heads and accountants; (iii) a set of core questions - with the same wording - are asked in the same way in all countries; ${ }^{15}$ (iv) there are common rules for sample design. This is the least standardized aspect of the surveys. The rules are the following: (i) each country survey contains a minimum set of sectors that are shared by a larger number of countries; (ii) major export and/or growth industries are adequately represented; (iii) for budget reasons, coverage is limited to areas of minimum concentration of activity; (iv) the sample should be representative of the sectors and regions it covers (and in particular of the main ones), i.e. each sector and region should contain at least 50-100 observations; (v) all samples must be stratified by size, sector and location. Depending on the country, the sample size for most recent ICS ranges from 200 to 1500 (depending on the size of the economy).

From the ICS database we have extracted responses on a specific question concerning labor regulations: "Please tell us if any of the following issues are a problem for the operation and growth of your business. If an issue poses a problem, please judge its severity on a four-point scale ${ }^{16}$ ". Eighteen issues are proposed including labor regulations. ${ }^{17}$

\footnotetext{
14 In cases where firms with several establishment have consolidated accounts, every effort is made to disaggregate. If this is not possible, the unit of observation is the same throughout the questionnaire.

15 These common questions constitute a well-tested product of past surveys having been pooled and consolidated from instruments of FACS, WBES and RPED surveys. Together they constitute 50 to 60 percent of the full survey instrument, the rest being items generating information for analyzing more specialized policy issues.

16 Where $0=$ no obstacle, $1=$ minor obstacle, $2=$ moderate obstacle, $3=$ major obstacle, $4=$ very severe obstacle. For our purpose and to make the variable consistent across WBES and ICS, we merge responses 3 and 4 into the category "major".

17 Telecommunications, electricity, transportation, access to land, tax rates, tax administration, custom and trade regulations, labor regulations, skills and education of available workers, business licensing and operating permits, access to financing, cost of financing, economic and regulatory policy
} 
Moreover, we have used the ICS database to assess firms' behavior along different dimensions, which are useful as controls in the empirical analysis and as possible behavioral responses to restrictions in hiring and firing. The variables include: basic firm characteristics; changes in employment over the previous two years ${ }^{18}$; whether the firm is upgrading its products or production line ${ }^{19}$; whether the firms hires temporary workers ${ }^{20}$; and finally whether the firm is providing training to its workers ${ }^{21}$ (see section 4 for more details on the empirical strategy).

Table 2 presents the sample sizes and basic characteristics of the firms involved in the WBES and ICS surveys and which have provided the information that is relevant to our study. Despite the different country coverage, firms' characteristics are fairly similar across the two surveys, as are the responses of firms concerning labor regulations. Across all firms surveyed in both the WBES and the ICS, close to 70 percent of respondents in WBES (60 percent in ICS) reported that labor market regulations represented an obstacle (minor, moderate, major) to their operation and expansion. Around 16 percent report that these regulations are a major obstacle to the operation and growth of their business in ICS (14 percent in WBES).

Table 2: Basic characteristics of the firms in the WBES and ICS databases

\begin{tabular}{llll|lll}
\hline & \multicolumn{3}{c}{ WBES } & \multicolumn{3}{c}{ ICS } \\
\hline & Mean & $\begin{array}{l}\text { Number } \\
\text { of } \\
\text { countries }\end{array}$ & $\begin{array}{l}\text { Number of } \\
\text { firms }\end{array}$ & Mean & $\begin{array}{l}\text { Number } \\
\text { of } \\
\text { countries }\end{array}$ & $\begin{array}{l}\text { Number } \\
\text { of firms }\end{array}$ \\
$\begin{array}{l}\text { Proportion of firms that: } \\
\text { Report EPL as no obstacle }\end{array}$ & 33.4 & 81 & 9070 & 44.1 & 47 & 17461 \\
Report EPL as minor obstacle & 28.6 & 81 & 9070 & 21.7 & 47 & 17461 \\
Report EPL as moderate obstacle & 23.8 & 81 & 9070 & 18.0 & 47 & 17461 \\
report EPL as major obstacle & 14.1 & 81 & 9070 & 16.1 & 47 & 17461 \\
are small (less than 20 employees) & 40.7 & 81 & 9070 & 41.7 & 47 & 17461 \\
are medium (21 to 100 employees) & 41.5 & 81 & 9070 & 31.9 & 47 & 17461 \\
are large (over 100 employees) & 17.8 & 81 & 9070 & 26.4 & 47 & 17461 \\
are owned by the government & & & & 10.0 & 47 & 17461 \\
expanded employment & 54.4 & & 4664 & 71.0 & 47 & 17140 \\
upgraded or created a product line & - & & - & 66.7 & 39 & 14043 \\
provide formal training & - & & - & 56.1 & 38 & 12170 \\
hire temporary workers & - & & - & 41.7 & 38 & 10837 \\
Average age of firms & 18.6 & 81 & 9070 & 16.0 & 47 & 17461 \\
\hline
\end{tabular}

\section{4. $\quad$ The empirical analysis}

\section{Modeling firms' perceptions}

uncertainty, macroeconomic instability, corruption, crime, theft and disorder, anti-competitive or informal practices, and legal system/conflict resolution.

${ }_{18} \quad$ Firm increased employment between the previous year and the year before.

19 Firm developed a major new product line and/or upgraded an existing product line in the previous three years.

20 Dummy $=1$ if firms employ temporary workers, 0 otherwise.

21 Firms report whether they offer formal (beyond "on the job") training to their regular employees. 
In a first stage, we model the determinants of the perception that employers have of labor market regulations. Using a generalized ordered logit model, ${ }^{22}$ we regress the perception of labor regulations on an index of strictness of actual regulations as defined in the law, and a set of control variables. We assume that the perception of the strictness of labor regulations is a continuous latent variable $y^{*}$ which represents utility or preferences and is unobservable:

$y^{*}=X \beta+\varepsilon \quad \varepsilon \mid X \sim$ standard logistic distribution.

where $\beta$ is a $\mathrm{K} \times 1$ vector and $X$ contains $\mathrm{K}$ explanatory variables (described below). While $y^{*}$ is not observed, the response to the above question $(y)$ is, and is considered as the manifestation of these preferences. $y$ is defined in the following way:

$$
\begin{aligned}
& y=0 \text { if } y^{*} \leq \alpha_{1} \\
& y=1 \text { if } \alpha_{1}<y^{*} \leq \alpha_{2} \\
& \ldots \\
& y=3 \text { if } y^{*}>\alpha_{3}
\end{aligned}
$$

where $\alpha_{\mathrm{i}}$ is an unknown cut point.

Following the theoretical and empirical background provided in section 2, there are two sets of basic explanatory variables which are likely to influence employers' perceptions: (i) firms' characteristics; (age, size of firm, and ownership); (ii) external conditions, for example, enforcement of regulations or economic conditions (captured through the country's income level and region dummies). Firm's perceptions are also likely to depend on the firm's current situation. We capture this in two ways: (1) by adding the innovating history of the firm (whether it upgraded or created a product line in the three year before the survey) and (2) by adding whether it increased permanent employment. We then introduce in the model our variable of interest: actual de jure employment regulations, both as a stand-alone dummy and interacted with the firm's situation.

The generalized ordered logit model estimates a set of coefficients (including one for the constant) for each of the $\mathrm{m}-1$ points at which the dependent variable can be dichotomized. From this set of $\mathrm{k}$ coefficients $\left(\mathrm{B}_{\mathrm{k}}\right)$, using the logistic cumulative distribution, it is straightforward to derive formulas for the probabilities that $y$ will take on each of the values $0,1, \ldots, \mathrm{m}$ :

$$
\mathrm{P}(y=0)=\mathrm{F}\left(-\mathrm{X} \beta_{1}\right)
$$

22 To estimate an ordered logit model, Stata imposes what is called the proportional odds assumption on the data. Having tested our model, we concluded that this assumption did not hold. The generalized ordered logit model relaxes the proportional odds assumption and allows the effects of the explanatory variables to vary with the point at which the categories of the dependent variable are dichotomized (Maddala, 1983, p46). 


$$
\begin{aligned}
& \mathrm{P}(y=\mathrm{j})=\mathrm{F}\left(-\mathrm{X} \beta_{(\mathrm{j}+1)}\right)-\mathrm{F}\left(-\mathrm{X} \beta_{\mathrm{j}}\right) \quad \mathrm{j}=1, \ldots, \mathrm{m}-1 \\
& \mathrm{P}(y=\mathrm{m})=1-\mathrm{F}\left(-\mathrm{X} \beta_{\mathrm{m}}\right)
\end{aligned}
$$

In specifications which include the innovating history of the firm, it can be argued that this variable is likely to be endogenous as the perceptions that employers have of labor market regulations may influence their propensity to innovate. This problem can only be solved if we are able to find a satisfactory instrument for the innovating history (i.e. a variable that is correlated with the innovating history but not with perceptions). The ICS provide information regarding the sources of the firm's working capital. We measure the proportion of capital that comes from formal credit institutions ${ }^{23}$ as an indicator for access to credit. The instrumental variable estimation is done in two steps, we first estimate a first-stage logit regression of the innovating history on firms' characteristics and the instrument. We then include the fitted values of the first stage regression in the second stage model (described above) in place of the endogenous variable. To accommodate for the fact that fitted values are used, standard errors are calculated through bootstrapping.

\section{Modeling firms' behavior}

Having shown the extent to which perceived and de jure labor regulations are correlated, in a second stage, we model the behavior of firms as a function of their perception of labor regulations, actual regulations and firm characteristics. We are interested in the way in which firms adapt their behavior to the constraints of labor regulations. In particular we look at two choices of firms:

- Provision of training. Since regulations make it harder for firms to fire workers, they may have an incentive to increase the human capital of their workers by offering them training.

- Use of temporary employment. As discussed above, the extent to which firms rely on temporary workers is likely to depend on the combination of regulations of regular employment on the one hand and temporary employment on the other hand.

The independent variable of interest is the degree to which firms find actual regulations to be an obstacle to their business. We recognize however that employers' perceptions of labor market regulations are likely to be endogenous to firms' behavior. We therefore use in subsequent specifications our measures of de jure regulations instead of perceptions; through the analysis in our first stage described above, we provide an assessment the quality of this proxy. We add combinations of variables measuring the strictness of regular and temporary employment regulations. We include these two types of

\footnotetext{
${ }^{23}$ Formal credit institutions are the following: local commercial banks, foreign owned commercial banks, leasing arrangement, investment funds, special development financing, other state services, trade credit, credit cards, equity, sales of stock. Other sources of capital include: internal funds or retained earnings, family, friends, informal sources (e.g. money lenders).
} 
regulations separately because, they are likely to have differential effects on the provision of training and the use of temporary workers. The other control variables are as follows: (i) firms' characteristics (age, size of firm, industry, innovating history, and ownership) and (ii) country's income level.

The propensity to provide training or use temporary workers is not observed, we only observe whether firms have actually provided training or employed temporary workers. Moreover, the use of temporary instead of regular employment and the provision of training are not independent choices for firms. Depending on the regulatory environment in which firms operate, the underlying technology of the firm and its size and other salient characteristics, training may be an alternative to the use of temporary workers e.g. when training allows skills adjustment which can alternatively be obtained by recruiting temporary workers, or even a complement-when it is difficult to recruit skilled workers on a temporary basis.

We therefore test the hypothesis that these two decisions are endogenous and use a bivariate probit model to consider training provision and the use of temporary employment simultaneously. In other words, we model the reaction of firms in a two-equations model:

$$
\begin{array}{ll}
y_{1}^{*}=X_{1} \beta_{1}+\varepsilon_{1}, & y_{1}=1 \text { if } y_{1}^{*}>0,0 \text { otherwise } \\
y_{2}^{*}=X_{2} \beta_{2}+\varepsilon_{2}, & y_{2}=1 \text { if } y_{2}^{*}>0,0 \text { otherwise }
\end{array}
$$

Where $y_{1,2} *$ are two unobservable latent variables representing the propensity to provide training and employ temporary workers, and $y_{1,2}$ the observable reactions of firms, namely providing training and employing temporary workers. The random error terms, $\varepsilon_{1,2}$ are normally distributed with $\mathrm{E}\left[\varepsilon_{1}\right]=\mathrm{E}\left[\varepsilon_{2}\right]=0$, and $\operatorname{var}\left[\varepsilon_{1}\right]=\operatorname{var}\left[\varepsilon_{2}\right]=1$ but they could be correlated, i.e. $\operatorname{cov}\left[\varepsilon_{1}, \varepsilon_{2}\right]=\rho$. If a Wald test shows that $\rho$ is not statistically different from zero then there is no endogeneity bias and the two models can be estimated separately as standard probits. If however $\rho$ is significantly different from zero and the log-likelihood of the bivariate estimate is significantly less than the joint binomial probit log-likelihoods, then $y_{1}$ and $y_{2}$ are endogenous processes (Bertaut 1998; Greene 2003). Wald tests are reported in Tables $7 \mathrm{a}, \mathrm{b}, \mathrm{c}$ and all show that the two processes considered here are indeed endogenous (they reject the hypothesis that $\rho$ is equal to zero at the 1 to 5 percent level of significance), we therefore present results only for the bivariate probit model.

The probabilities that enter the likelihood function are given by the bivariate cumulative distribution function (Greene, 2003):

$$
\begin{aligned}
\operatorname{Prob}\left(\mathrm{Y}_{1}=y_{\mathrm{i} 1}, \mathrm{Y}_{2}=y_{\mathrm{i} 2}\right)= & \Phi\left(w_{\mathrm{i} 1}, w_{\mathrm{i} 2}, \rho_{\mathrm{i}}{ }^{*}\right) \\
& =\int_{-\infty}^{w_{i 2}} \int_{-\infty}^{w_{i 1}} \varphi\left(z_{\mathrm{i} 1}, z_{i 2}, \rho_{\mathrm{i}}{ }^{*}\right) d z_{i 1} d z_{i 2}
\end{aligned}
$$


where

$z_{\mathrm{ij}}=\beta_{\mathrm{j}}^{\prime} X_{\mathrm{ij}} \quad$ and $\quad w_{\mathrm{ij}}=\left(2 y_{\mathrm{ij}}-1\right) \beta_{\mathrm{j}} X_{\mathrm{ij}} \quad$ with $\quad \mathrm{j}=1,2$

$\rho_{\mathrm{i}}^{*}=\left(2 y_{\mathrm{i} 1}-1\right)\left(2 y_{\mathrm{i} 2}-1\right) \rho$

and

$\varphi\left(w_{\mathrm{i} 1}, w_{i 2}, \rho_{\mathrm{i}}^{*}\right)=\frac{\exp \left[-1 / 2\left(w_{i 1}^{2}+w_{i 2}^{2}-2 \rho_{\mathrm{i}}^{*} w_{i 1} w_{i 2}\right) /\left(1-\rho_{\mathrm{i}}^{*}\right)\right.}{2 \pi\left(1-\rho_{\mathrm{i}} *^{2}\right)^{1 / 2}}$

$\Phi$ is the bivariate normal cumulative distribution function and $\varphi$ is the bivariate normal density function.

It can be argued that firms have also the choice of adjusting the number of permanent staff. We therefore extend our model to take into account this additional potential behavior. The bivariate probit model can be extended to include additional probit equations, to become a trivariate, or even multivariate probit model ( $M$-equation model). However, the estimation problem is complicated by the fact that, as can be seen from the formulae above, M-dimensional Normal integrals have to be evaluated in the likelihood function. The solution commonly used is to evaluate the integrals with the GHK (Geweke-Hajivassiliou-Keane) smooth recursive simulator. ${ }^{24}$

\section{Clustering}

The inclusion of the employment protection legislation indicators in our models raises an important methodological issue. These indicators only vary across countries and standard errors can be seriously biased downwards (see Moulton, 1990). This is the case, because standard errors are likely to be correlated for observations within each country, especially when the explanatory variable is auto-correlated over time and/or across different units within one country. All the estimations of this paper therefore take this into consideration by relaxing the assumption of independence of observations that is usually made; we assume that observations are independent across countries, but not necessarily across firms in the same country. In addition, the estimations assume that observations may not be identically distributed. The cluster adjustment made to the variance-covariance matrix are standard and described in Rogers (1993) and Williams (2000).

\section{Results}

In the empirical analysis we test three key hypotheses formulated in the theoretical literature and discussed in previous empirical studies.

- As shown above, a significant share of firms across many countries find labor regulations to be an obstacle to their operation and growth. Do these perceptions vary depending on firms' characteristics, performance and innovation projects?

\footnotetext{
${ }^{24}$ For references and a brief description of the GHK smooth recursive simulator see Greene (2003).
} 
- We also want to assess whether employers' perceptions about labor regulations are consistent with de jure EPL across countries. This allows to see whether empirical results based on surveys and those based on synthetic indicators of formal regulations can be compared. Even more importantly, assessing the links between perceptions and formal regulations can tell us something about enforcement of rules in different countries. To the extent these links vary depending of firm characteristics and performance, we can shed light on who is most affected by a given regulatory setting.

- Finally, we link the perceived and formal stringency of labor regulations to two possible strategies firms can use to, at least partially, overcome them: making greater use of training to adapt the workforce to changes in technology instead of recurring to the external labor market; and make greater use of temporary employment to increase labor flexibility when regulations of regular contracts are too constraining.

\section{What makes employers worry about labor regulations?}

Table 3 presents the generalized ordered logit regressions of the perceived constraint of labor regulations drawing from both the WBES and the ICS samples. ${ }^{25}$ In this and in Table 4, we present the marginal effects of the independent variables on the probability that the respondent reports labor regulations as no obstacle or as a major obstacle. ${ }^{26}$ In the first four columns in Table 3, we only include firms' characteristics - age, size, geographical area, and ownership-and the country income group as explanatory variables of firms' perception. Other things being equal, young or small firms appear less concerned with labor regulations, while, older, or medium and large firms (more than 20 employees) are more likely to report that these regulations are an obstacle to their business.

Not surprisingly, firms which are at least partly owned by the government show less concern for labor regulations than those completely private. Large employment adjustments in state-owned enterprises often involve large and generous packages transferring, at least partially, the adjustment costs to taxpayers.

The regional dummies and the income group dummies allow to shed some light on the different degree of enforcement of regulations across countries. Given the unavoidable major labor reallocation coupled and assisted by large use of early retirement and generous mass layoffs schemes in transition economies, it is not surprising to find that, other things being equal, firms in these countries appear the least concerned compared to other regions (except Middle East and North Africa which is not found to differ significantly from firms in transition countries). The results also suggest that the higher

\footnotetext{
25 The different specifications use the largest available sample of firms/countries. However, to verify the robustness of results across specifications, we also re-run them on the same maximum common sample. This sensitivity analysis suggests that the results are robust to the use of a smaller common sample. The results are available from the authors upon request.

26 The estimated marginal probabilities that respondents report minor or moderate constraint (i.e. the other two options in the questionnaire of the two surveys) are available from the authors.
} 
the income level of a country, the greater the likelihood that firms find labor regulations to be an obstacle to their business, other things being equal. This may be due to the fact that more developed countries have more stringent regulations on labor or that enforcement improves with economic development. We go back to this issue below when we introduce formal regulations in the equation.

In the second set of specifications (columns 5 to 8 ) in Table 3, we also include controls for firm performance: innovation (whether the firm is upgrading its production line or its products) and expansion of employment. Consistently with theory, firms that are innovating are more likely to report that labor regulations are a significant source of constraint. Most of the time, innovation involves the adoption of new technologies that require new skills and labor regulations, by raising the costs of adjusting the workforce, may make it more difficult or costly to do so. The results are not significantly changed when controlling for potential endogeneity of this variable (Table A1 in Annex 3). Not surprisingly, firms that increased the number of full-time staff are found, other things being equal, to be less concerned by labor regulations than others. The perception about labor regulation and the decision to change the workforce are obviously correlated. We use the change in employment to characterize the general performance of the firm (whether it is expanding or downsizing) and, to reduce the obvious endogeneity problem, we use the lagged values of the employment change. Moreover, results in Tables 3 and 4 show that all other coefficients are robust to the inclusion of this variable.

In Table 4 we turn to the effects of formal regulations on employers' perceptions. We use the same basic controls discussed above and add our EPL indicators in levels and in interactions with firm size and changes in employment. The main result is that even controlling for firm characteristics, income per capita and geographical location of the countries, de jure regulations are consistent with employers' perceptions: firms facing stricter EPL are less likely than others to report that labor regulations are not an obstacle to their business, and are more likely to report that regulations are a major obstacle to their operation (columns 1,2,5, and 6). We should note here that the effect of countries' income level does not disappear (results not shown in Table 4): firms in countries with higher income level are more likely to report that labor regulations are a constraint, even controlling for the strictness of actual de jure labor regulations.

As stressed above, the link between actual regulations and perceptions of regulations is likely to be influenced by firm's characteristics and behavior. This is analyzed by allowing the coefficients of EPL to vary depending on firm size (columns 3, 4, 7 and 8). While all firms perceive regulations more constraining in countries with strict EPL, in both the WBES and especially in the ICS data, medium-sized firms are more severely affected (the coefficients on medium-size firms are significantly larger in absolute value than coefficients for small and large firms). This is consistent with the hypothesis of a "forgotten middle" (e.g. Scarpetta et al., 2002; Batra et al., 2003). Small firms are often exempted from certain aspects of labor regulations (Boeri and Jimeno, 2003). In many countries where enforcement of regulations is limited, small firms do not comply, remaining invisible to regulators and inspectors. For large firms, hiring and firing costs 
play a smaller role in total expected costs of adjusting the workforce. ${ }^{27}$ In addition, they are often able to overcome at least partially these costs by obtaining special treatment from the local or national authorities or by exploiting their strong bargaining power. Firms of medium size are sufficiently large to be visible to the authorities and thus unable to avoid regulations, but not large enough to dilute the associated costs of these regulations via internal mobility or special arrangement with the authorities.

We also test whether the sensitivity of employers' perception to de jure EPL varies depending on firms' performance (expanding or not) and innovation (Table 4, columns 9 to 12). While there is no evidence that firms' expansion influences the link between perception and EPL, firms which have upgraded their production line or created new products are more likely to report more severe constraints to regulations in countries with stringent EPL. ${ }^{28}$ Again this confirms that EPL may be particularly problematic when firms have to change the skill composition of the workforce to better use new technologies and production process. Put in another way, strict EPL may reduce incentives for firms to invest in new technologies or develop new products with potentially negative effects on aggregate productivity and growth potential.

\section{Do training and temporary employment allow firms to overcome strict EPL?}

Strict labor regulations are likely to influence firms' management of labor. We expect that stringent hiring and firing regulations will give incentives for firms to make greater use of training, other things being equal (see also Young, 2003). At the same time, if EPL is stringent we expect firms to make greater use of temporary employment to increase their adaptability to demand fluctuations, especially if regulations for temporary employment are relatively less stringent than those for regular employment.

Tables 5 and 6 present the univariate probabilities of providing training or use temporary employment drawn from the bivariate probit, while Table 7 (a, b and c) presents the probabilities for the four different possible combinations of training and temporary employment decisions. Table 7a focuses on specifications that include the basic controls for firms' characteristics and external conditions; Table 7b extends the analysis to include EPL for regular and temporary contracts; and finally Table 7c looks at the effects of asymmetric EPL for regular and temporary workers on training and use of temporary contracts. We construct dummy variables that identify the four possible combinations: strict temporary and strict regular - strict-TER-strict-PER; strict-TER-lax-RER, lax-TERlax-RER, lax-TER-strict-RER. ${ }^{29}$

A number of results emerge:

27 Indeed, the incidence of strict EPL on total labor adjustment costs may decline with the size of the firm, as larger ones may more easily reallocate labor within them and spread these costs over a larger capital stock.

${ }_{28}$ While the coefficients of "Overall EPL and expanding employment" is not significantly different from that of "Overall EPL and contracting employment", the coefficients of "Overall EPL and Innovator" and "Overall EPL and Not innovator" are significantly different from each other.

${ }_{29}$ The strictness of regulations is defined by comparing regulations across countries in two ways: (i) values below (above or equal to) the median value for each variable and (ii) values below (above or equal to) the mean value for each variable. 
- Firms that perceive regulations as constraining are somewhat more likely to use temporary workers and training to adjust the workforce (Table 5, column 1; Table 6, column 1). More interestingly, firms being constrained by labor regulations have a stronger probability to both provide training and use temporary employment than neither or one but not the other (Table 7a).

- While temporary employment is more prominently used by mid-sized firms, rather than small or large firms, training is more diffused in medium and large firms (Tables 5 and 6). At the same time, medium and large sized firms are more likely to provide training and not use temporary employment - controlling for their perception of regulations - than smaller firms. Medium and large firms are also less likely to use temporary employment without training (Table 7a). All in all, training is more frequent amongst medium and large firms, while the use of temporary workers is more diffused amongst small firms. Extending the model to include the strategy of not increasing permanent employment (Table A2 in Annex 3 ), the pattern is unchanged for medium and large firms. Small firms are found to favor stable or decreasing employment over the use of temporary workers and especially of training. Compared to medium and large firms, small firms are less likely to use all three strategies (Table A3 in Annex 3).

- Firms that are upgrading their production process or introducing new product lines are more likely to use temporary employment and, especially they provide more training (Tables 5 and 6). Again, they are more likely to use both than neither and more likely to use training but not temporary employment than vice versa (Table 7a). As could be expected, they are also less likely to decrease or keep employment stable (Table A2).

- Turning to de jure regulations, we find that EPL for regular contracts has a strong effect on firms' decision to provide training and make greater use of temporary employment. Moreover, more stringent regular employment regulations are found to discourage firms to decrease or keep employment stable, although the effect is small. By contrast, EPL for temporary contracts does not discriminate firms' behavior significantly ${ }^{30}$ (columns 2 and 3 in Tables 5 and 6; Table 7b).

- Firms' reaction also depends on the relative importance of regular and temporary employment regulations. Lowering temporary while leaving in place strict regulations for regular employment does not change significantly the probability of providing training. Not surprisingly, firms facing strict regulations for temporary contracts but lax regulations for regular contracts are less likely to hire temporary workers instead of regular workers, although this result is based on weak evidence (Table 6, columns 4 and 5). In addition, facing stringent regular and temporary employment regulations discourages firms to lower or keep employment stable (Table A2). certain aspects of the regulatory system (e.g. they do not consider temporary work agencies and procedural inconveniences for setting up a temporary contract). 
- The stringency of regular employment regulations appears to be what really discriminates between the provision of training and the use of temporary workers (Table 7c). Firms facing stringent employment regulations for regular workers are more likely to use both instruments. In addition, there is some evidence that firms in these countries tend to prefer training to employing temporary workers. There is also some evidence that increasing the stringency of temporary employment regulations push firms towards making greater use of training instead of employment workers under temporary contracts. (Table 7c).

Overall, these results suggest that liberalizing temporary employment regulations while leaving in place strict regulations for regular employment may not lead to a substitution of training for more temporary employment. Most likely firms will expand both. In other words, at least in our sample of developing and transition economies, training seems to be the main reaction of firms to strict regulations on regular contracts, while the use of temporary employment is a complement for larger firms, while an alternative solution for smaller firms that have difficulties in providing training.

\section{Concluding remarks}

In this paper we look at how employment protection legislation is perceived by employers in a wide range of industrial, developing and transition economies. We draw from harmonized firm surveys compiled by the World Bank and compare the results from these surveys with indicators of de jure labor laws. We also assess how employers react when constrained by strict labor regulations. In particular, we look at whether they make greater use of on-the-job training instead of hiring and firing workers to upgrade the skills of the workforce, or whether they use more temporary employment to enhance the adaptability of the workforce to the evolution of demand.

Our main results can be summarized as follows:

- Employers' perceptions are broadly consistent with de jure labor regulations. In a large sample of developing, transition and industrial countries, employers' concerns about labor market regulations are closely matched by the relative stringency of de jure labor laws. In countries with labor regulations are more stringent from an international perspective, a larger number of employers report that these legislations are a major or severe constraint to their operation, even after controlling for factors that may influence the varying degree of law enforcement.

- Not all firms are affected in the same way by strict labor regulations. Mediumsize firms are the ones most severely affected. This is probably because in many countries where enforcement of regulations is limited small firms do not comply, remaining invisible to regulators and inspectors. And for large firms, hiring and firing costs play a smaller role in total expected costs of adjusting the workforce. By contrast, firms of medium size are sufficiently large to be visible to the authorities and thus unable to avoid regulations, but not large enough to use 
internal mobility as an alternative to hiring and firing or obtain special arrangements with the authorities to dilute the associated costs.

- Innovating firms - those that have upgraded their production process or their products -- are more likely to face severe constraints from strict labor regulations. This points to the importance of labor regulations for innovation adoption of new technology and potentially long-term growth.

- Firms react to strict employment regulations by investing more in training and making greater use of temporary employment. Not all firms can use these strategies, though. Medium and large firms tend to use both training and temporary employment, while small firms tend to rely more on the use of temporary employment when facing strict regulations. Innovating firms make greater use of training than temporary employment to upgrade skills.

All in all, this paper suggests that labor laws have an impact on firms' performance. Medium-size firms -- those that often have the greatest potential for expansion and creating more jobs - are the most severely affected as are innovating firms that require adjustment in the workforce to match the requirements of new technologies. Training and temporary employment are used to circumvent the costs associated with strict labor regulations for regular contracts, but again not all firms can take advantage of these strategies.

For the empirical research agenda, the good news is that de jure indicators of the stringency of labor regulations are broadly consistent with employers' survey data. Hence results from studies relying on either one or the other type of information can be compared and used for informing policy makers. But our results clearly suggest that EPL affects firms differently, depending on their characteristics and performance. And although some of them use training or temporary employment to compensate for the high costs associated with EPL, we do not know how costly these strategies are for firms and their job creation potential. These are issues that deserve a closer look in future empirical work. 
Table 3: Firms' characteristics and perception of strictness of labor regulations (Marginal effects from Generalized Ordered Logit Model)

\begin{tabular}{|c|c|c|c|c|c|c|c|c|}
\hline & \multicolumn{2}{|c|}{ WBES } & \multicolumn{6}{|c|}{ ICS } \\
\hline & $\begin{array}{l}\text { No } \\
\text { obstacle }\end{array}$ & $\begin{array}{l}\text { Major } \\
\text { obstacle }\end{array}$ & $\begin{array}{l}\text { No } \\
\text { obstacle }\end{array}$ & $\begin{array}{l}\text { Major } \\
\text { obstacle }\end{array}$ & $\begin{array}{l}\text { No } \\
\text { obstacle }\end{array}$ & $\begin{array}{l}\text { Major } \\
\text { obstacle }\end{array}$ & $\begin{array}{l}\text { No } \\
\text { obstacle }\end{array}$ & $\begin{array}{l}\text { Major } \\
\text { obstacle }\end{array}$ \\
\hline \multicolumn{9}{|c|}{ Age (Less than 5 years old) } \\
\hline 5 to 15 years old & $\begin{array}{l}-0.035^{*} \\
(0.014\end{array}$ & $\begin{array}{l}0.004 \\
(0.003)\end{array}$ & $\begin{array}{l}-0.018 \\
(0.012)\end{array}$ & $\begin{array}{l}0.005^{* *} \\
(0.002)\end{array}$ & $\begin{array}{l}-0.012 \\
(0.012)\end{array}$ & $\begin{array}{l}0.004 * * \\
(0.001)\end{array}$ & $\begin{array}{l}-0.019 \\
(0.014)\end{array}$ & $\begin{array}{l}0.006^{*} \\
(0.003)\end{array}$ \\
\hline 16 or more & $\begin{array}{l}-0.069 * * \\
(0.019\end{array}$ & $\begin{array}{l}0.011+ \\
(0.006)\end{array}$ & $\begin{array}{l}0.005 \\
(0.020)\end{array}$ & $\begin{array}{l}0.009 * * \\
(0.003)\end{array}$ & $\begin{array}{l}0.018 \\
(0.020)\end{array}$ & $\begin{array}{l}0.007^{*} \\
(0.003)\end{array}$ & $\begin{array}{l}0.011 \\
(0.022)\end{array}$ & $\begin{array}{l}0.010^{* *} \\
(0.004)\end{array}$ \\
\hline Ownership (Public) & $\begin{array}{l}0.059^{* *} \\
0.017\end{array}$ & $\begin{array}{l}-0.010^{* *} \\
(0.003)\end{array}$ & $\begin{array}{l}0.022 \\
(0.021)\end{array}$ & $\begin{array}{l}-0.008^{* *} \\
(0.002)\end{array}$ & $\begin{array}{l}0.012 \\
(0.022)\end{array}$ & $\begin{array}{l}-0.007 * * \\
(0.002)\end{array}$ & $\begin{array}{l}0.029 \\
(0.024)\end{array}$ & $\begin{array}{l}-0.011^{* *} \\
(0.003)\end{array}$ \\
\hline \multicolumn{9}{|c|}{ Size (Less than 20 employees) } \\
\hline 20 to 100 employees & $\begin{array}{l}-0.081 * * \\
(0.021)\end{array}$ & $\begin{array}{l}0.015^{* *} \\
(0.004)\end{array}$ & $\begin{array}{l}-0.095 * * \\
(0.023)\end{array}$ & $\begin{array}{l}0.014 * * \\
(0.003)\end{array}$ & $\begin{array}{l}-0.071 * * \\
(0.022)\end{array}$ & $\begin{array}{l}0.011 * * \\
(0.003)\end{array}$ & $\begin{array}{l}-0.096 * * \\
(0.023)\end{array}$ & $\begin{array}{l}0.017 * * \\
(0.004)\end{array}$ \\
\hline $\begin{array}{l}\text { More than } 100 \\
\text { employees }\end{array}$ & $\begin{array}{l}-0.106^{* *} \\
(0.027)\end{array}$ & $\begin{array}{l}0.004 \\
(0.004)\end{array}$ & $\begin{array}{l}-0.177 * * \\
(0.027)\end{array}$ & $\begin{array}{l}0.020 * * \\
(0.005)\end{array}$ & $\begin{array}{l}-0.156^{* *} \\
(0.027)\end{array}$ & $\begin{array}{l}0.016^{* *} \\
(0.004)\end{array}$ & $\begin{array}{l}-0.178 * * \\
(0.027)\end{array}$ & $\begin{array}{l}0.023 * * \\
(0.005)\end{array}$ \\
\hline \multicolumn{9}{|l|}{ Region (ECA) } \\
\hline SSA & $\begin{array}{l}-0.312 * * \\
(0.067)\end{array}$ & $\begin{array}{l}0.046+ \\
(0.026)\end{array}$ & $\begin{array}{l}-0.125 \\
(0.094)\end{array}$ & $\begin{array}{l}0.049+ \\
(0.025)\end{array}$ & $\begin{array}{l}-0.230 * * \\
(0.060)\end{array}$ & $\begin{array}{l}0.042 * \\
(0.017)\end{array}$ & $\begin{array}{l}-0.141 \\
(0.093)\end{array}$ & $\begin{array}{l}0.057^{*} \\
(0.028)\end{array}$ \\
\hline EAP & $\begin{array}{l}-0.112 \\
(0.076)\end{array}$ & $\begin{array}{l}0.017 \\
(0.016)\end{array}$ & $\begin{array}{l}-0.185 * * \\
(0.056)\end{array}$ & $\begin{array}{l}0.055^{* *} \\
(0.012)\end{array}$ & $\begin{array}{l}-0.175 * * \\
(0.057)\end{array}$ & $\begin{array}{l}0.044 * * \\
(0.010)\end{array}$ & $\begin{array}{l}-0.192 * * \\
(0.056)\end{array}$ & $\begin{array}{l}0.064 * * \\
(0.014)\end{array}$ \\
\hline INL & $\begin{array}{l}-0.164 * \\
(0.080)\end{array}$ & $\begin{array}{l}0.048^{*} \\
(0.023)\end{array}$ & & & & & & \\
\hline LAC & $\begin{array}{l}-0.21 * * \\
(0.057)\end{array}$ & $\begin{array}{l}0.056^{*} \\
(0.026)\end{array}$ & $\begin{array}{l}-0.192 \\
(0.128)\end{array}$ & $\begin{array}{l}0.107^{*} \\
(0.054)\end{array}$ & $\begin{array}{l}-0.154 \\
(0.117)\end{array}$ & $\begin{array}{l}0.076+ \\
(0.040)\end{array}$ & $\begin{array}{l}-0.206 \\
(0.128)\end{array}$ & $\begin{array}{l}0.128^{*} \\
(0.063)\end{array}$ \\
\hline MENA & $\begin{array}{l}-0.012 \\
(0.139)\end{array}$ & $\begin{array}{l}-0.008 \\
(0.010)\end{array}$ & $\begin{array}{l}-0.085^{* *} \\
(0.032)\end{array}$ & $\begin{array}{l}0.023 * * \\
(0.006)\end{array}$ & & & $\begin{array}{l}-0.094^{* *} \\
(0.034\end{array}$ & $\begin{array}{l}0.028 * * \\
(0.007)\end{array}$ \\
\hline SAS & $\begin{array}{l}-0.529 * * \\
(0.033)\end{array}$ & $\begin{array}{l}0.173 * * \\
(0.058)\end{array}$ & $\begin{array}{l}-0.272 * * \\
(0.064)\end{array}$ & $\begin{array}{l}0.057^{*} \\
(0.027)\end{array}$ & & & $\begin{array}{l}-0.291 * * \\
(0.062)\end{array}$ & $\begin{array}{l}0.070 * \\
(0.032)\end{array}$ \\
\hline \multicolumn{9}{|c|}{ Country income level (Low) } \\
\hline Lower Middle & $\begin{array}{l}-0.193 * * \\
(0.062)\end{array}$ & $\begin{array}{l}0.040+ \\
(0.021)\end{array}$ & $\begin{array}{l}-0.121 * \\
(0.057)\end{array}$ & $\begin{array}{l}0.021 \\
(0.014)\end{array}$ & $\begin{array}{l}-0.124 * \\
(0.054)\end{array}$ & $\begin{array}{l}0.018 \\
(0.012)\end{array}$ & $\begin{array}{l}-0.126^{*} \\
(0.059)\end{array}$ & $\begin{array}{l}0.023 \\
(0.016)\end{array}$ \\
\hline Upper Middle or high & $\begin{array}{l}-0.211 * * \\
(0.065)\end{array}$ & $\begin{array}{l}0.031 \\
(0.020)\end{array}$ & $\begin{array}{l}-0.243 * * \\
(0.086)\end{array}$ & $\begin{array}{l}0.046 \\
(0.033)\end{array}$ & $\begin{array}{l}-0.238 * * \\
(0.084)\end{array}$ & $\begin{array}{l}0.039 \\
(0.027)\end{array}$ & $\begin{array}{l}-0.246^{* *} \\
(0.085)\end{array}$ & $\begin{array}{l}0.053 \\
(0.038)\end{array}$ \\
\hline Innovator & & & & & $\begin{array}{l}-0.076^{* *} \\
(0.015)\end{array}$ & $\begin{array}{l}0.007 * * \\
(0.002)\end{array}$ & & \\
\hline Expanded employment & & & & & & & $\begin{array}{l}0.047 * * \\
(0.011)\end{array}$ & $\begin{array}{l}-0.005^{* *} \\
(0.001)\end{array}$ \\
\hline $\begin{array}{l}\text { Observations } \\
\text { (number of countries }{ }^{31} \text { ) }\end{array}$ & $\begin{array}{l}9070 \\
(81)\end{array}$ & $\begin{array}{l}9070 \\
(81)\end{array}$ & $\begin{array}{l}17461 \\
(47)\end{array}$ & $\begin{array}{l}17461 \\
(47)\end{array}$ & $\begin{array}{l}14043 \\
(39)\end{array}$ & $\begin{array}{l}14043 \\
(39)\end{array}$ & $\begin{array}{l}17140 \\
(47)\end{array}$ & $\begin{array}{l}17140 \\
(47)\end{array}$ \\
\hline $\begin{array}{l}\text { Predicted probability at } \\
\text { the mean }\end{array}$ & 0.335 & 0.141 & 0.441 & 0.161 & 0.440 & 0.169 & 0.440 & 0.161 \\
\hline
\end{tabular}

${ }^{31}$ Lists of countries are reported in Annex 2 for all the samples in all tables. 


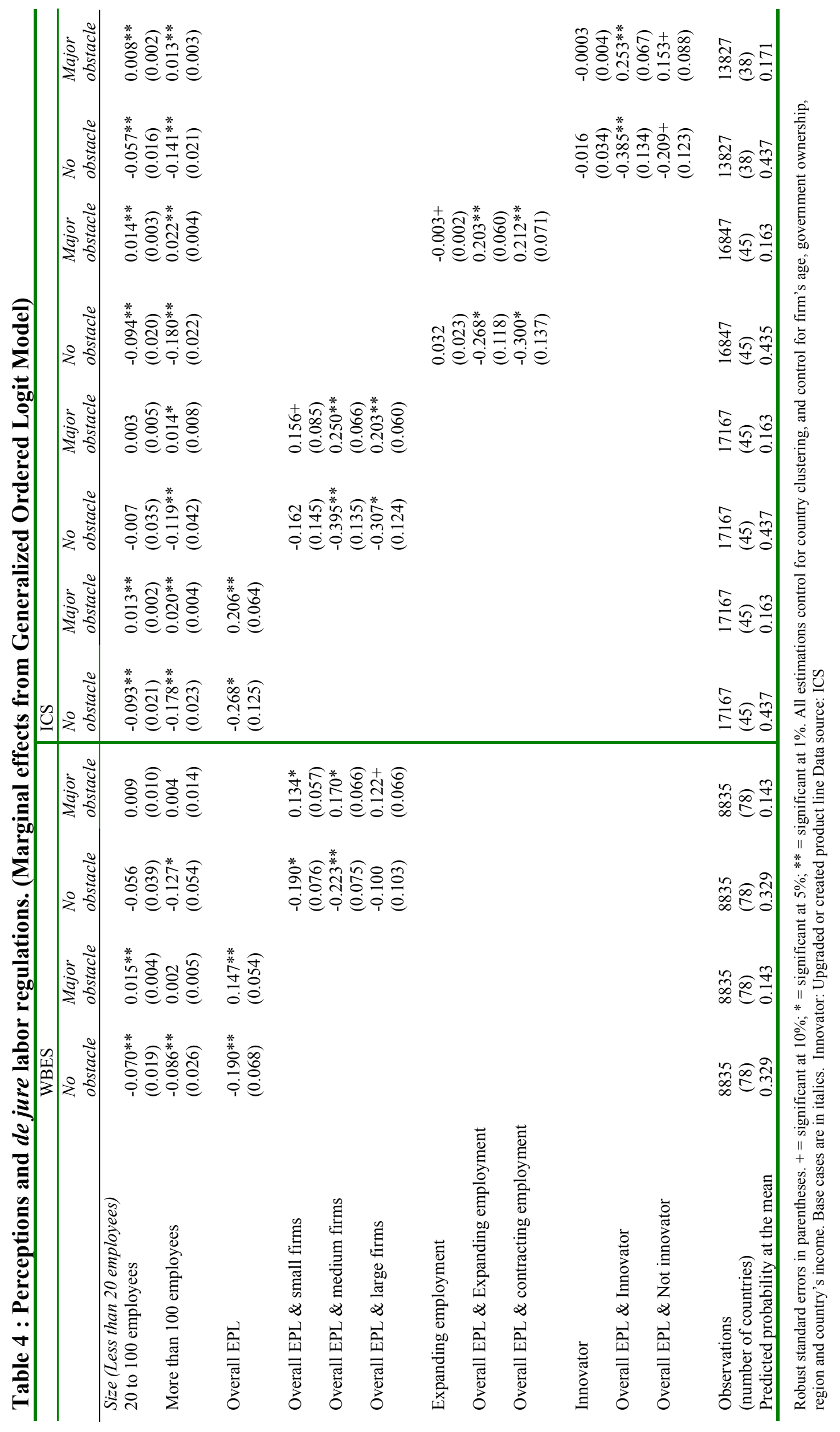


Table 5: The determinants of training provision (Marginal effects from the Bivariate Probit model)

\begin{tabular}{|c|c|c|c|c|c|}
\hline & $(1)$ & $(2)$ & (3) & (4) & $(5)$ \\
\hline \multicolumn{6}{|l|}{ Perceptions (No obstacle) } \\
\hline Minor obstacle & $\begin{array}{l}0.011 \\
(0.018)\end{array}$ & & & & \\
\hline Moderate obstacle & $\begin{array}{l}0.061 \\
(0.022) * *\end{array}$ & & & & \\
\hline Major obstacle & $\begin{array}{l}0.058 \\
(0.038)\end{array}$ & & & & \\
\hline \multicolumn{6}{|l|}{ Age (Less than 5 years old) } \\
\hline 5 to 15 years old & $\begin{array}{l}0.012 \\
(0.019)\end{array}$ & $\begin{array}{l}0.009 \\
(0.017)\end{array}$ & $\begin{array}{l}0.008 \\
(0.018)\end{array}$ & $\begin{array}{l}0.013 \\
(0.018)\end{array}$ & $\begin{array}{l}0.013 \\
(0.018)\end{array}$ \\
\hline 16 or more & $\begin{array}{l}-0.043 \\
(0.032)\end{array}$ & $\begin{array}{l}-0.026 \\
(0.024)\end{array}$ & $\begin{array}{l}-0.052 \\
(0.030)+\end{array}$ & $\begin{array}{l}-0.025 \\
(0.026)\end{array}$ & $\begin{array}{l}-0.023 \\
(0.025)\end{array}$ \\
\hline Ownership (Public) & $\begin{array}{l}0.075 \\
(0.026)^{* *}\end{array}$ & $\begin{array}{l}0.055 \\
(0.028)+\end{array}$ & $\begin{array}{l}0.078 \\
(0.024)^{* *}\end{array}$ & $\begin{array}{l}0.048 \\
(0.024)^{*}\end{array}$ & $\begin{array}{l}0.050 \\
(0.026)+\end{array}$ \\
\hline Innovator & $\begin{array}{l}0.143 \\
(0.034)^{* *}\end{array}$ & $\begin{array}{l}0.168 \\
(0.025)^{* *}\end{array}$ & $\begin{array}{l}0.137 \\
(0.037)^{* *}\end{array}$ & $\begin{array}{l}0.176 \\
(0.024)^{* *}\end{array}$ & $\begin{array}{l}0.182 \\
(0.025) * *\end{array}$ \\
\hline \multicolumn{6}{|l|}{ Size (Less than 20 employees) } \\
\hline 20 to 100 employees & $\begin{array}{l}0.181 \\
(0.022)^{* *}\end{array}$ & $\begin{array}{l}0.165 \\
(0.020)^{* *}\end{array}$ & $\begin{array}{l}0.192 \\
(0.022) * *\end{array}$ & $\begin{array}{l}0.160 \\
(0.020)^{* *}\end{array}$ & $\begin{array}{l}0.160 \\
(0.020)^{* *}\end{array}$ \\
\hline More than 100 employees & $\begin{array}{l}0.287 \\
(0.021)^{* *}\end{array}$ & $\begin{array}{l}0.263 \\
(0.020) * *\end{array}$ & $\begin{array}{l}0.303 \\
(0.020)^{* *}\end{array}$ & $\begin{array}{l}0.260 \\
(0.021)^{* *}\end{array}$ & $\begin{array}{l}0.259 \\
(0.021)^{* *}\end{array}$ \\
\hline Sector (Manufacturing) & $\begin{array}{l}-0.024 \\
(0.036)\end{array}$ & $\begin{array}{l}-0.011 \\
(0.039)\end{array}$ & $\begin{array}{l}-0.012 \\
(0.035)\end{array}$ & $\begin{array}{l}-0.028 \\
(0.036)\end{array}$ & $\begin{array}{l}-0.028 \\
(0.036)\end{array}$ \\
\hline \multicolumn{6}{|l|}{ Country income level (Low income) } \\
\hline Lower Middle income & $\begin{array}{l}0.138 \\
(0.062)^{*}\end{array}$ & $\begin{array}{l}0.163 \\
(0.060)^{* *}\end{array}$ & $\begin{array}{l}0.137 \\
(0.065)^{*}\end{array}$ & $\begin{array}{l}0.169 \\
(0.057)^{* *}\end{array}$ & $\begin{array}{l}0.163 \\
(0.065)^{*}\end{array}$ \\
\hline Upper Middle income or high income & $\begin{array}{l}0.317 \\
(0.056)^{* *}\end{array}$ & $\begin{array}{l}0.351 \\
(0.052)^{* *}\end{array}$ & $\begin{array}{l}0.324 \\
(0.054)^{* *}\end{array}$ & $\begin{array}{l}0.370 \\
(0.046)^{* *}\end{array}$ & $\begin{array}{l}0.363 \\
(0.049)^{* *}\end{array}$ \\
\hline \multicolumn{6}{|l|}{ Labor regulations indexes } \\
\hline \multicolumn{2}{|l|}{ Regular employment } & $\begin{array}{l}0.614 \\
(0.127)^{* *}\end{array}$ & & & \\
\hline \multicolumn{2}{|l|}{ Temporary employment } & & $\begin{array}{l}0.095 \\
(0.100)\end{array}$ & & \\
\hline \multicolumn{6}{|c|}{ Regulatory mix - median (Low TER and low RER) } \\
\hline High TER and High RER & & & & $\begin{array}{l}0.215 \\
(0.053)^{* *}\end{array}$ & \\
\hline Low TER and High RER & & & & $\begin{array}{l}0.219 \\
(0.050)^{* *}\end{array}$ & \\
\hline High TER and Low RER & & & & $\begin{array}{l}0.122+ \\
(0.063)\end{array}$ & \\
\hline \multicolumn{6}{|c|}{ Regulatory mix - mean (Low TER and low RER) } \\
\hline High TER and High RER & & & & & $\begin{array}{l}0.185 \\
(0.052)^{* *}\end{array}$ \\
\hline Low TER and High RER & & & & & $\begin{array}{l}0.210 \\
(0.049)^{* *}\end{array}$ \\
\hline High TER and Low RER & & & & & $\begin{array}{l}0.014 \\
(0.079)\end{array}$ \\
\hline Observations (number of countries) & $9676(38)$ & & & & \\
\hline Predicted probability at the mean & 0.568 & 0.570 & 0.569 & 0.570 & 0.570 \\
\hline
\end{tabular}

Robust standard errors in parentheses (and adjusted for clustering on country). $+=$ significant at $10 \%$; * significant at $5 \%$; $* *$ significant at $1 \%$. Where relevant, base categories of dummies are indicated in parentheses in italics. Data source: ICS. 
Table 6: The determinants of the use if temporary workers used (Marginal effects from the Bivariate Probit model)

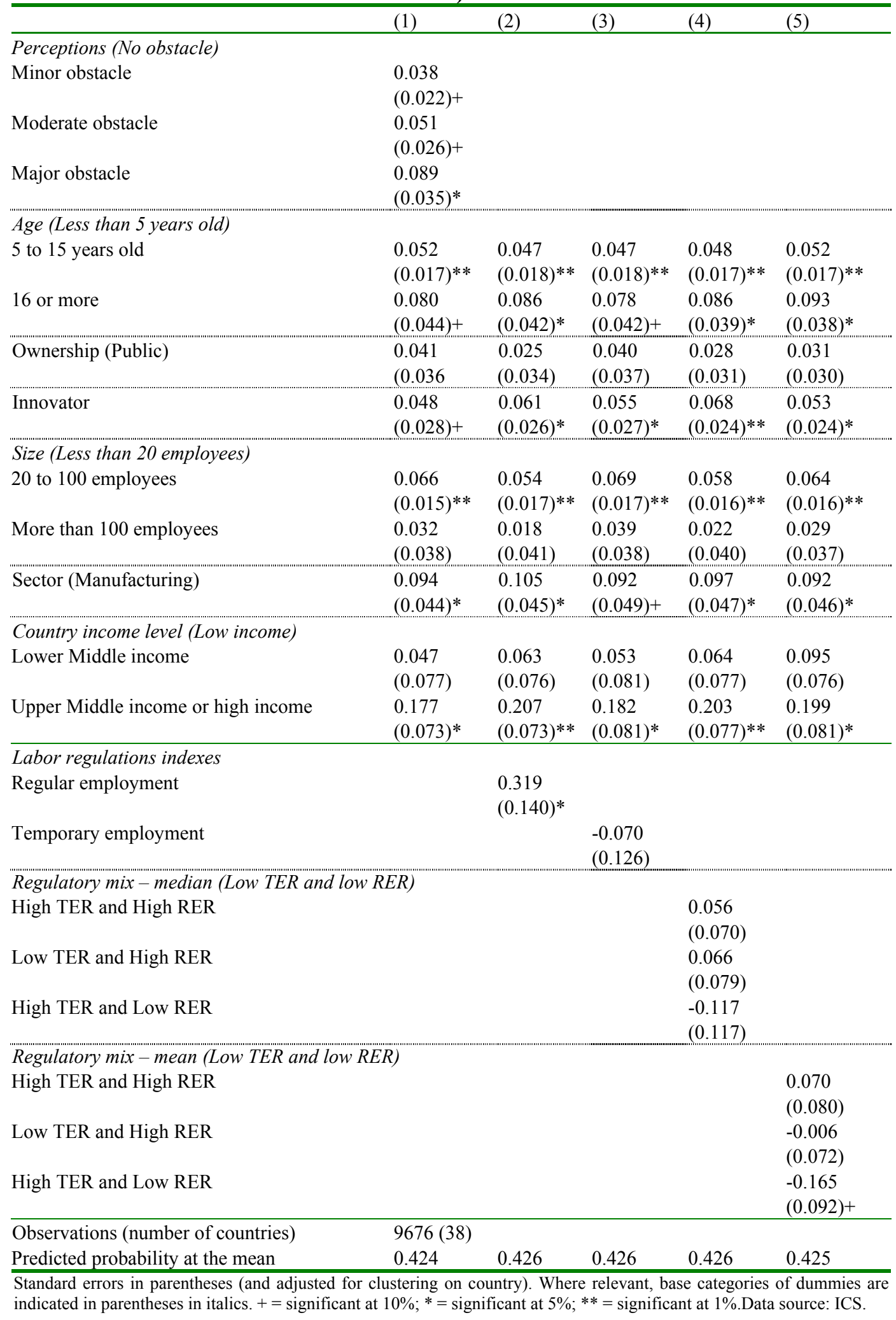


Table 7a: The determinants of training provision and use of temporary workers (Marginal effects from the Bivariate Probit model)

\begin{tabular}{|c|c|c|c|c|}
\hline & $\begin{array}{l}\text { Provides training } \\
\text { and employs } \\
\text { temporary workers }\end{array}$ & $\begin{array}{l}\text { Does not provide } \\
\text { training and } \\
\text { s employs temporary } \\
\text { workers }\end{array}$ & $\begin{array}{l}\text { Provides training } \\
\text { and does not } \\
\text { employ } \\
\text { temporary } \\
\text { workers }\end{array}$ & $\begin{array}{l}\text { Does not provide } \\
\text { training and does } \\
\text { not employ } \\
\text { temporary workers }\end{array}$ \\
\hline \multicolumn{5}{|l|}{ Perceptions (No obstacle) } \\
\hline Minor obstacle & $\begin{array}{l}0.027 \\
(0.018)\end{array}$ & $\begin{array}{l}0.011 \\
(0.009)\end{array}$ & $\begin{array}{l}-0.016 \\
(0.012)\end{array}$ & $\begin{array}{l}-0.022 \\
(0.016)\end{array}$ \\
\hline Moderate obstacle & $\begin{array}{l}0.057 \\
(0.020)^{* *}\end{array}$ & $\begin{array}{l}-0.006 \\
(0.014)\end{array}$ & $\begin{array}{l}0.005 \\
(0.019)\end{array}$ & $\begin{array}{l}-0.055 \\
(0.017)^{* *}\end{array}$ \\
\hline Major obstacle & $\begin{array}{l}0.079 \\
(0.029)^{* *}\end{array}$ & $\begin{array}{l}0.010 \\
(0.024)\end{array}$ & $\begin{array}{l}-0.021 \\
(0.029)\end{array}$ & $\begin{array}{l}-0.068 \\
(0.023)^{* *}\end{array}$ \\
\hline \multicolumn{5}{|l|}{ Age (Less than 5 years old) } \\
\hline 5 to 15 years old & $\begin{array}{l}0.035 \\
(0.011)^{* *}\end{array}$ & $\begin{array}{l}0.017 \\
(0.012)\end{array}$ & $\begin{array}{l}-0.023 \\
(0.018)\end{array}$ & $\begin{array}{l}-0.029 \\
(0.012)^{*}\end{array}$ \\
\hline 16 or more & $\begin{array}{l}0.026 \\
(0.031) \\
\end{array}$ & $\begin{array}{l}0.053 \\
(0.022)^{* *}\end{array}$ & $\begin{array}{l}-0.069 \\
(0.025)^{* *}\end{array}$ & $\begin{array}{l}-0.010 \\
(0.031)\end{array}$ \\
\hline Ownership (Public) & $\begin{array}{l}0.057 \\
(0.021)^{* *}\end{array}$ & $\begin{array}{l}-0.016 \\
(0.021)\end{array}$ & $\begin{array}{l}0.018 \\
(0.029)\end{array}$ & $\begin{array}{l}-0.060 \\
(0.019)^{* *}\end{array}$ \\
\hline Innovator & $\begin{array}{l}0.086 \\
(0.024)^{* *}\end{array}$ & $\begin{array}{l}-0.038 \\
(0.015)^{*}\end{array}$ & $\begin{array}{l}0.057 \\
(0.025)^{*}\end{array}$ & $\begin{array}{l}-0.105 \\
(0.026)^{* *}\end{array}$ \\
\hline \multicolumn{5}{|l|}{ Size (Less than 20 employees) } \\
\hline 20 to 100 employees & $\begin{array}{l}0.117 \\
(0.014)^{* *}\end{array}$ & $\begin{array}{l}-0.052 \\
(0.013)^{* *}\end{array}$ & $\begin{array}{l}0.064 \\
(0.017)^{* *}\end{array}$ & $\begin{array}{l}-0.130 \\
(0.015)^{* *}\end{array}$ \\
\hline More than 100 employees & $\begin{array}{l}0.140 \\
(0.026)^{* *}\end{array}$ & $\begin{array}{l}-0.108 \\
(0.018)^{* *}\end{array}$ & $\begin{array}{l}0.147 \\
(0.030)^{* *}\end{array}$ & $\begin{array}{l}-0.179 \\
(0.022)^{* *}\end{array}$ \\
\hline Sector (Manufacturing) & $\begin{array}{l}0.044 \\
(0.029)\end{array}$ & $\begin{array}{l}0.050 \\
(0.024)^{*}\end{array}$ & $\begin{array}{l}-0.068 \\
(0.030)^{*}\end{array}$ & $\begin{array}{l}-0.026 \\
(0.031)\end{array}$ \\
\hline \multicolumn{5}{|l|}{ Country income level (Low income) } \\
\hline Lower Middle income & $\begin{array}{l}0.084 \\
(0.059)\end{array}$ & $\begin{array}{l}-0.036 \\
(0.033)\end{array}$ & $\begin{array}{l}0.054 \\
(0.046)\end{array}$ & $\begin{array}{l}-0.101 \\
(0.059)+\end{array}$ \\
\hline Upper Middle income or high income & $\begin{array}{l}0.263 \\
(0.072)^{* *}\end{array}$ & $\begin{array}{l}-0.086 \\
(0.023)^{* *}\end{array}$ & $\begin{array}{l}0.054 \\
(0.048)\end{array}$ & $\begin{array}{l}-0.231 \\
(0.045)^{* *}\end{array}$ \\
\hline Observations (number of countries) & $9676(38)$ & & & \\
\hline Predicted probability at the mean & 0.259 & 0.165 & 0.309 & 0.267 \\
\hline Wald test for rho $=0$ & Chi2 $(1)=6.612 ; \mathrm{P}$ & rob $>\operatorname{chi} 2=0.010$ & & \\
\hline
\end{tabular}




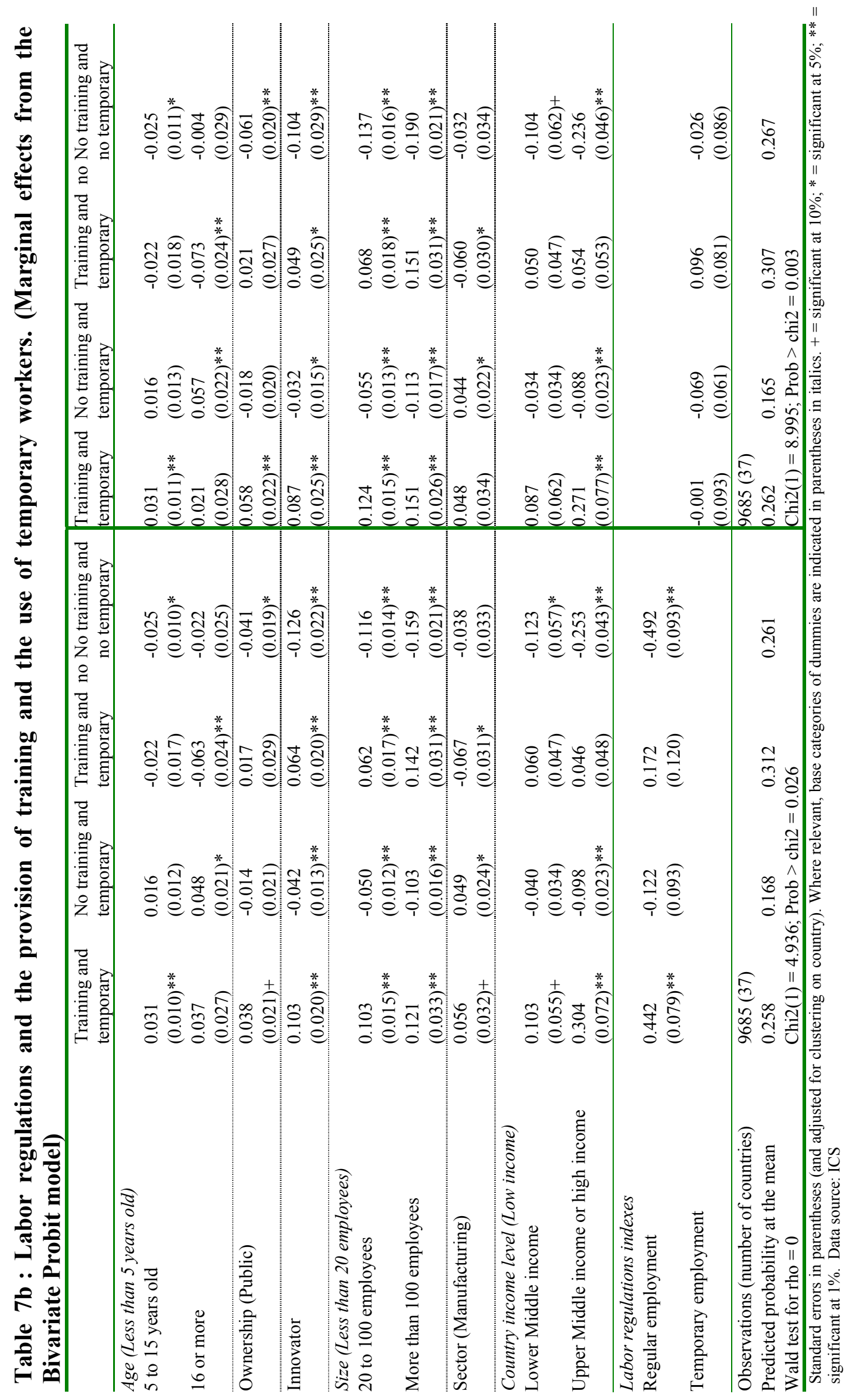




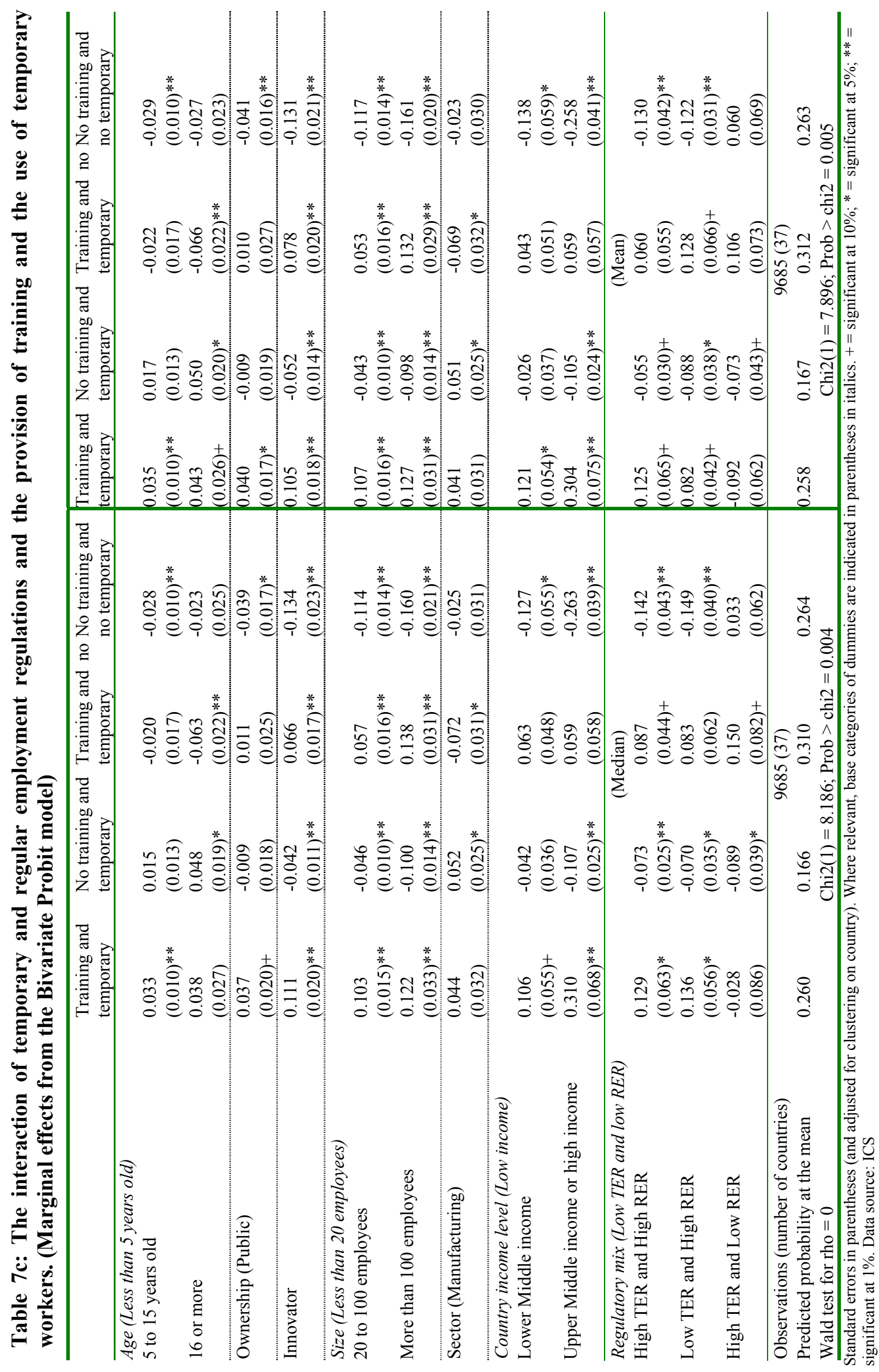




\section{References}

Acemoglu, D. and S. Pischke (1998), "Why Do Firms Train? Theory and Evidence", Quarterly Journal of Economics, vol. 113, pp. 79-119.

Acemoglu, D. and S. Pischke (1999), "Beyond Becker: Training in Imperfect Labor Markets", Economic Journal, vol. 109, pp. F112-142.

Addison, J. and J. Teixeira (2003), "The Economics of Employment Protection", Journal of Labor Research 24, pp. 85-129.

Akerlof, G. (1984), An Economist's Book of Tales, Cambridge University Press, Cambridge.

Alvarez, F. and M. Varacierto (2001), "Severance Payments in an Economy with Frictions", Journal of Monetary Economics, vol. 47, pp. 477-498.

Batra, G., Kaufmann, D. and A. Stone (2003), Investment Climate Around the World. Voices of the Firms from the World Business Environment Survey, The World Bank, Washington DC.

Belot, M. and J. van Ours (2000), "Does the Recent Success of Some OECD Countries in Lowering their Unemployment Rates Lie in the Clever Design of their Labour Market Reforms", IZA Discussion Paper, no. 147, April.

Bentolila, S. and G. Bertola (1990), "Firing Costs and Labour Demand: How Bad is Eurosclerosis?", Review of Economic Studies, no. 57, pp. 381-402.

Bentolila, S. and J.J. Dolado (1994), "Labour Flexibility and Wages: Lessons from Spain”, Economic Policy, no. 18, April.

Bertaut, C. (1998), "Stockholding Behavior of U.S. Households: Evidence from the 1983-1989 Survey of Consumer Finances", Review of Economics and Statistics 80(2), pp. 263-75.

Bertola, G. (1990), "Job Security, Employment and Wages", European Economic Review, vol. 34, North Holland, pp. 851-886.

Bertola, G. (1992), "Labour Turnover Costs and Average Labour Demand", Journal of Labour Economics, no. 4.

Bertola, G.. 2004. "A Pure Theory of Job Security and Labor Income Risk." Review of Economic Studies, vol 71, no. 1, pp. 43-61.

Bertola, G. and R. Rogerson (1997), "Institutions and Labor Reallocation", European Economic Review, vol. 41, pp. 1147-1171.

Bertola, G., Boeri, T., Cazes, S. (2000), "Employment Protection in Industrialized Countries: the Case for New Indicators", International Labor Review 139, pp. 57-72.

Besley, T. and R.Burgess (2004), "Can Labor Regulation Hinder Economic Performance? Evidence from India”, Quarterly Journal of Economics, vol. 119, no. 1, pp. 91-134.

Blanchard, O. and A. Landier (2002), "The Perverse Effect of Partial Labour Market Reform: Fixed-Term Contracts in France", Economic Journal, vol. 112, no. 480, pp. F214-244.

Blanchard, O. and J. Wolfers (2000), "The Role of Shocks and Institutions in the Rise of European Unemployment: The Aggregate Evidence", Economic Journal, vol. 110, no. 462, pp. C1-33.

Blanchard, O. and P. Portugal (2001), "What Hides Behind an Unemployment Rate: Comparing Portuguese and U.S. Labor Markets", American Economic Review 91, pp. 187-207.

Blinder, A. and A. Krueger (1996), "Labor Turnover in the USA and Japan: A Tale of Two Countries", Pacific Economic Review, vol. 1, pp. 27-57. 
Boeri, T. (1999), "Enforcement of Employment Security Regulations, On-the-job Search and Unemployment Duration”, European Economic Review, vol. 43, pp. 65-89.

Boeri, T. and J. Jimeno, (2003), "The Effects of Employment Protection: Learning from Variable Enforcement”, CEPR Discussion Papers, no. 3926.

Boeri, T., and M. Burda (2004), "Preferences for Rigid versus Individualized Wage Setting in Search Economies with Firing Frictions", mimeo.

Cappelli, P. (2000), "Examining the Incidence of Downsizing and Its Effect on Establishment Performance", in D. Neumark (ed.), On the Job, New York: Russell Sage Foundation.

Cappelli, P. and D. Neumark (2001), "External Job Churning and Internal Job Flexibility”, NBER Working Paper, no. 8111.

Chandra, V., L. Moorty, J-P1 Nganou, B. Rajaratnam, and K.Schaefer (2001), "Constraints to Growth and Employment in South Africa: Report no.2 Evidence from the Small, Medium and Micro Enterprise Firm Survey".

De Barros, R.P. and C.H. Conseuil (2004), "The Impact of Regulations on Brazilian Labor Market Performance", in James Heckman and Carmen Pagés, eds., Law and Employment: Lessons from the Latin America and the Caribbean. Cambridge, Mass. and Chicago, I.L.: National Bureau of Economic Research and University of Chicago, pp. 273-350.

Di Tella R. and R. MacCulloch (forthcoming), "The Consequences of Labor Market Flexibility: Panel Evidence Based on Survey Data", European Economic Review.

Djankov, S., R. La Porta, F. López-de-Silanes, A. Shleifer, and J. Botero (2003), “The Regulation of Labor”, National Bureau of Economic Research Working Paper Series 9756. Cambridge, Mass.

Dolado, J., C. García-Serrano, and J.F. Jimeno (2001), "Drawing Lessons from the Boom of Temporary Employment in Spain”, Fundación de Estudios de Economía Aplicada 2001-11. Madrid.

Elmeskov, J., J.P. Martin and S. Scarpetta (1998), "Key Lessons for Labour Market Reforms: Evidence from OECD Countries’ Experience”, Swedish Economic Policy Review, vol. 5, pp. 205-252.

Freeman R.B. (2001), Institutional differences and Economic Performance among OECD countries, Paper presented at the Bank of Portugal Conference "Labor Market Institutions and Economic Outcomes", Cascais, Portugal, June.

Gittleman M, M. Horrigan and M. Joyce (1998), “"Flexible” Workplace Practices: Evidence from a Nationally Representative Survey”, Industrial \& Labor Relations Review, vol. 52, no. 1, pp. 99-115.

Greene W. (2003), Econometric Analysis, Fifth Edition, Prentice Hall.

Grubb, D. and W. Wells (1993), "Employment Regulation and Patterns of Work in EC Countries", OECD Economic Studies, no. 21, OECD, Paris, Winter, pp. 7-58.

Heckman, J., Pagés, C. (2004), "Introductory Chapter", in J. Heckman and C. Pagés, eds., Law and Employment: Lessons from the Latin America and the Caribbean. Cambridge, Mass. and Chicago, I.L.: National Bureau of Economic Research and University of Chicago.

Hopenhayn, H. and R. Rogerson (1993), "Job Turnover and Policy Evaluation: A General Equilibrium Analysis", Journal of Political Economy, vol. 101, pp. 915-938.

Hopenhayn, H.. (2004), "Labor Market Policies and Employment Duration: The Effects of Labor Market Reform in Argentina", in James Heckman and Carmen Pagés, eds., Law and Employment: Lessons from the Latin America and the Caribbean. Cambridge, Mass. and Chicago, I.L.: National Bureau of Economic Research and University of Chicago, pp. 497-516. 
Ichino, A., M. Polo and E. Rettore (2003), “Are Judges Biased by Labour Market Conditions”, European Economic Review, vol. 47, no. 5, pp. 913-944.

Kugler, A. (2004), "The Effect of Job Security Regulations on Labor Market Flexibility: Evidence from the Colombian Labor Market Reform", in J. Heckman and C. Pagés, eds., Law and Employment:

Lessons from Latin America and the Caribbean. Cambridge, MA: NBER; and Chicago, IL: University of Chicago, pp. 183-228

Lazear, E.P. (1990), “Job Security Provisions and Employment”, The Quarterly Journal of Economics, August, pp. 699-726.

Lindbeck, A., and D.J. Snower (1988), The Insider-Outsider Theory of Employment and Unemployment, MIT Press, Cambridge, Massachusetts.

Lynch, L. (1994) (ed.), Training and the Private Sector: International Comparisons, Chicago: University of Chicago Press for the NBER.

Maddala G. (1983), Limited-dependent and Qualitative Variables in Econometrics, Econometric Society Monographs, Cambridge University Press.

Moulton, B. (1990), "An Illustration of a Pitfall in Estimating the Effects of Aggregate Variables on Micro Units", Review of Economics and Statistics 72, pp. 334-338.

Nickell, S. (1997), "Unemployment and Labor Market Rigidities: Europe versus North America", Journal of Economic Perspectives, vol. 11, no. 3, Summer, pp. 55-74.

Nickell, S., L. Nunziata and W. Ochel (2003), "Unemployment in the OECD since the 1960s: What Do We Know?", mimeo, Bank of England.

Nickell, S., L. Nunziata, W. Ochel and G. Quintini (2001), "The Beveridge Curve, Unemployment and Wages in the OECD”, CEP Discussion Paper, no. 502.

Nickell, S. and R. Layard, (1999), Labor Market Institutions and Economic Performance. In: Ashenfelter, O., Card, D. (Eds.), Handbook of Labor Economics. New York and Oxford: Elsevier Science, NorthHolland.

Nicoletti, G. and S. Scarpetta (2004), "Do Regulatory Reforms in Product and Labor Markets Promote Employment? Evidence From OECD countries", mimeo.

Nicoletti, G., R. Haffner, S. Nickell, S. Scarpetta, and G, Zoega. (2001), "European Integration, Liberalization and Labor-Market Performance", in G. Bertola, T. Boeri, and G. Nicoletti, eds., Welfare and Employment in a United Europe. Cambridge, Mass.: MIT Press.

OECD (1999), Employment Outlook, Paris.

OECD (1994) OECD Jobs Study, Paris.

OECD (1998), Employment Outlook, Paris.

OECD (2004), Employment Outlook, Paris.

Pagés, C., and C.E. Montenegro (1999), "Job Security and the Age Composition of Employment: Evidence from Chile", Inter-American Development Bank, Office of the Chief Economist Working Paper Series 398. Washington, D.C.

Piore, M. (1986), Labor Market Flexibility, University of California, Berkeley, CA.

Rogers, W.H. (1993), "Regression Standard Errors in Clustered Samples", Stata Technical Bulletin 13, pp. 19-23.

Saavedra, J. and M. Torero. (2004), "Labor Market Reforms and Their Impact on Formal Labor Demand and Job Market Turnover: The Case of Peru", in J. Heckman and C. Pagés, eds., Law and 
Employment: Lessons from Latin America and the Caribbean. Cambridge, MA: NBER; and Chicago, IL: University of Chicago, pp. 131-182.

Saint Paul, G. (1996), Dual Labour Markets, The MIT Press, Cambridge Massachusetts.

Scarpetta, S. (1996), "Assessing the Role of Labour Market Policies and Institutional Settings on Unemployment: A Cross-Country Study”, OECD Economic Studies, no. 26, 1996/1.

Scarpetta, S., P. Hemmings, T. Tressel, and J. Woo (2002), "The Role of Policy and Institutions for Productivity and Firm Dynamics: Evidence from Micro and Industry Data", OECD Economics Department Working Paper 329, Paris.

Scarpetta, S., and T. Tressel (2004), "Boosting Productivity via Innovation and Adoption of New Technologies: Any Role for Labor Market Institutions?”, World Bank Working Research Paper Series 3273. Washington, D.C.

Williams, R. (2000), “A Note on Robust Variance Estimation for Cluster-Correlated Data”, Biometrics 56, pp. 645-646.

World Bank (2000), The World Business Environment Survey., http://info.worldbank.org/governance/wbes/index1.html

World Bank (2002), Brazil Jobs Report 24480-BR, World Bank, Washington, D.C.

World Bank (2003), The Russian Labor Market: Moving from Crisis to Recovery, World Bank, Washington, D.C.

World Bank (2004a), Doing Business Database, http://rru.worldbank.org/DoingBusiness/default.aspx

World Bank (2004b), Investment Climate Surveys, http://iresearch.worldbank.org/ics/jsp/index.jsp

World Bank (2004c), Doing Business in 2004, Understanding Regulation, Oxford University Press.

Young, D. (2003), "Employment Protection Legislation: its Economic Impact and the Case for Reform", European Economy Economic Papers, no. 186, European Commission. 


\section{Annex 1: Construction of Employment Protection Legislation Indexes}

The indexes are calculated from the raw data provided in the Doing Business Database (2005). All the variables range between 0 and 1. They are either zero-one dummies (no/yes) or they are normalized over the sample. Variables for which higher values (x) represent looser regulations are normalized according to the simple formula: $x_{N}=1-\left(\frac{x}{\max \left(x_{E}\right)}\right)$ while variables for which higher values represent stricter regulations are normalized in the following way: $x_{N}=1-\frac{\left(\max \left(x_{E}\right)-x\right)}{\left(\max \left(x_{E}\right)-\min \left(x_{E}\right)\right)}$ where $x_{\mathrm{N}}$ is the normalized value, $\max \left(x_{\mathrm{E}}\right)$ is the maximum value that the variable takes over the sample of countries considered here (83 countries contained in WBES and /or in ICS: Albania, Algeria, Argentina, Armenia, Azerbaijan, Bangladesh, Belarus, Bhutan, Bolivia, Bosnia and Herzegovina, Botswana, Brazil, Bulgaria, Cambodia, Cameroon, Canada, Chile, China, Colombia, Costa Rica, Cote d'Ivoire, Croatia, Czech Republic, Dominican Republic, Ecuador, Egypt, El Salvador, Estonia, Ethiopia, France, Georgia, Germany, Ghana, Guatemala, Haiti, Honduras, Hungary, India, Indonesia, Italy, Kazakhstan, Kenya, Kyrgyz Republic, Latvia, Lithuania, Macedonia, FYR, Madagascar, Malawi, Malaysia, Mexico, Moldova, Namibia, Nicaragua, Nigeria, Pakistan, Panama, Peru, Philippines, Poland, Portugal, Romania, Russian Federation, Senegal, Serbia and Montenegro, Singapore, Slovak Republic, Slovenia, South Africa, Spain, Sweden, Tanzania, Thailand, Tunisia, Turkey, Uganda, Ukraine, United Kingdom, United States, Uruguay, Uzbekistan, Venezuela, Zambia, and Zimbabwe)

The regular employment weighted index is constructed from the raw variables in the following way (weights in parentheses):

Procedures (1/2) The employer must notify a third party before dismissing one redundant employee? (1/6)

The employer needs the approval of a third party to dismiss one redundant worker? (1/6)

The law mandates retraining or replacement prior to dismissal? (1/6)

There are priority rules applying to dismissal or lay-offs? (1/6)

There are priority rules applying to re-employment? (1/6)

Is redundancy considered a "fair" ground for dismissal? (1/6)

Firing costs (1/2) Legally mandated notice period for redundancy dismissal (in weeks) after twenty years of continuous employment? Normalized (1/2)

Severance pay for redundancy dismissal as number of months for which full wages are payable after continuous employment of twenty years? Normalized (1/2)

The temporary employment regulation index is equal to the simple average of the following variables:

Fixed-term contracts are only allowed for fixed-term tasks?

What is the maximum duration of fixed-term contracts (in months)? Normalized

Finally, the overall employment regulation index is the simple average of the regular and temporary employment indexes. 


\section{Annex 2: Countries included in estimation samples.}

Sample of 78 countries (WBES Table 4): Albania, Argentina, Armenia, Azerbaijan, Bangladesh, Belarus, Bolivia, Bosnia and Herzegovina, Botswana, Brazil, Bulgaria, Cambodia, Cameroon, Canada, Chile, China, Colombia, Costa Rica, Cote d'Ivoire, Croatia, Czech Republic, Dominican Republic, Ecuador, Egypt, El Salvador, Estonia, Ethiopia, France, Georgia, Germany, Ghana, Guatemala, Haiti, Honduras, Hungary, India, Indonesia, Italy, Kazakhstan, Kenya, Kyrgyz Republic, Lithuania, Madagascar, Malawi, Malaysia, Mexico, Moldova, Namibia, Nicaragua, Nigeria, Pakistan, Panama, Peru, Philippines, Poland, Portugal, Romania, Russian Federation, Senegal, Singapore, Slovak Republic, Slovenia, South Africa, Spain, Sweden, Tanzania, Thailand, Tunisia, Turkey, Uganda, Ukraine, United Kingdom, United States, Uruguay, Uzbekistan, Venezuela, Zambia, and Zimbabwe.

Sample of 81 countries (WBES Table 3): Sample of 78 countries plus: Belize, Trinidad \& Tobago, West Bank-Gaza.

Sample of 38 countries (Table 4): Albania, Armenia, Azerbaijan, Belarus, Bosnia and Herzegovina, Brazil, Bulgaria, Cambodia, China, Croatia, Czech Republic, Ecuador, Estonia, Georgia, Guatemala, Honduras, Hungary, Indonesia, Kazakhstan, Kyrgyz Republic, Latvia, Lithuania, Macedonia FYR, Malaysia, Moldova, Nicaragua, Philippines, Poland, Romania, Russian Federation, Serbia and Montenegro, Slovak Republic, Slovenia, Tanzania, Turkey, Ukraine, Uzbekistan, and Zambia.

Sample of 39 countries (ICS Table 3): Sample f 38 countries plus: Tajikistan.

Sample of 45 countries (ICS Table 4): Sample of 38 countries plus: Algeria, Bangladesh, Ethiopia, India, Kenya, Pakistan, Uganda.

Sample of 47 countries (ICS Table 3): Sample of 39 countries plus: Algeria, Bangladesh, Eritrea, Ethiopia, India, Kenya, Pakistan, Uganda.

Sample of 38 countries (ICS Tables 5, 6, 7): Albania, Armenia, Azerbaijan, Belarus, Bosnia and Herzegovina, Brazil, Bulgaria, Cambodia, China, Croatia, Czech Republic, Ecuador, Estonia, Georgia, Guatemala, Honduras, Hungary, Kazakhstan, Kyrgyz Republic, Latvia, Lithuania, Macedonia FYR, Malaysia, Moldova, Nicaragua, Philippines, Poland, Romania, Russian Federation, Serbia and Montenegro, Slovak Republic, Slovenia, Tajikistan, Tanzania, Turkey, Ukraine, Uzbekistan, Zambia. 


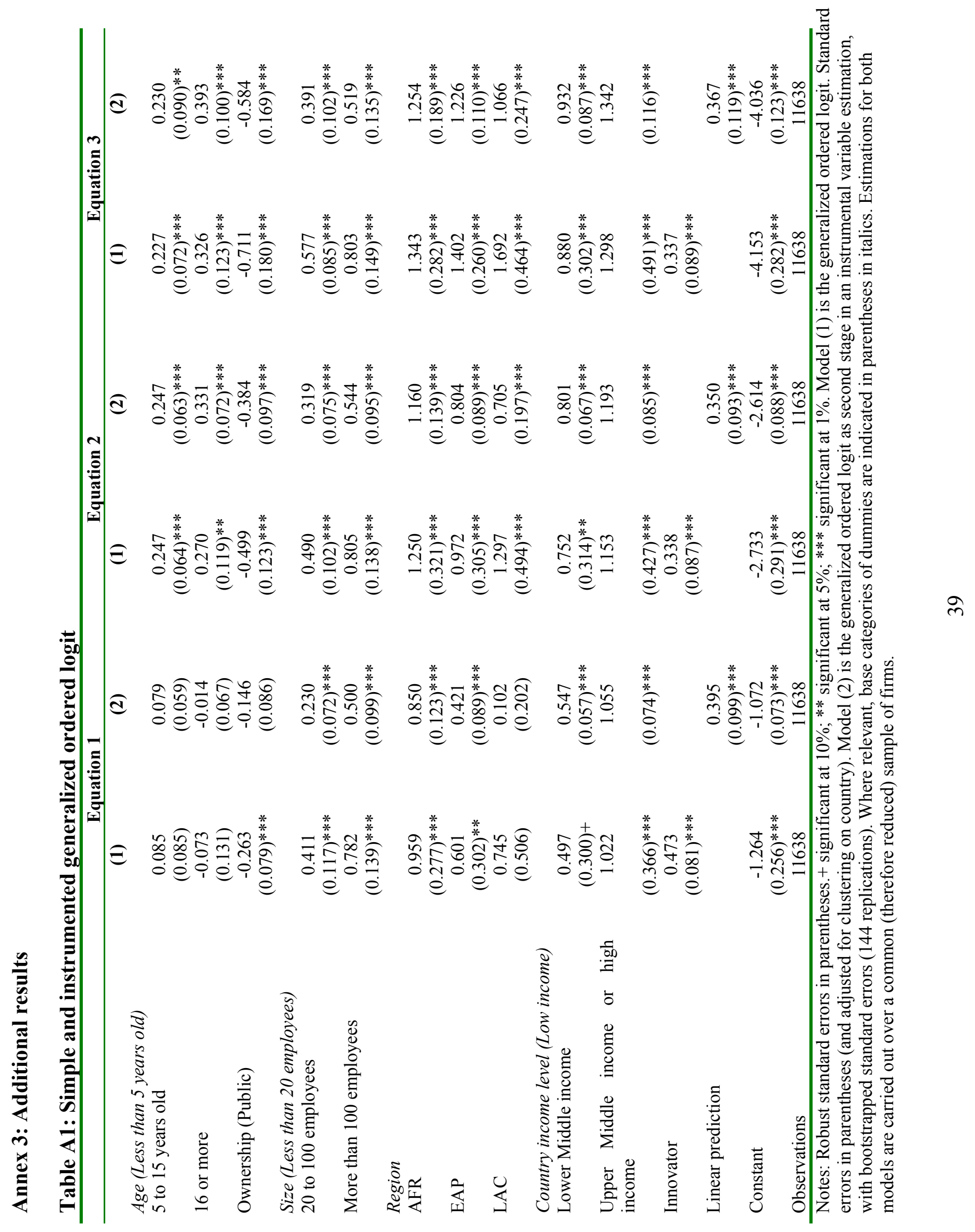




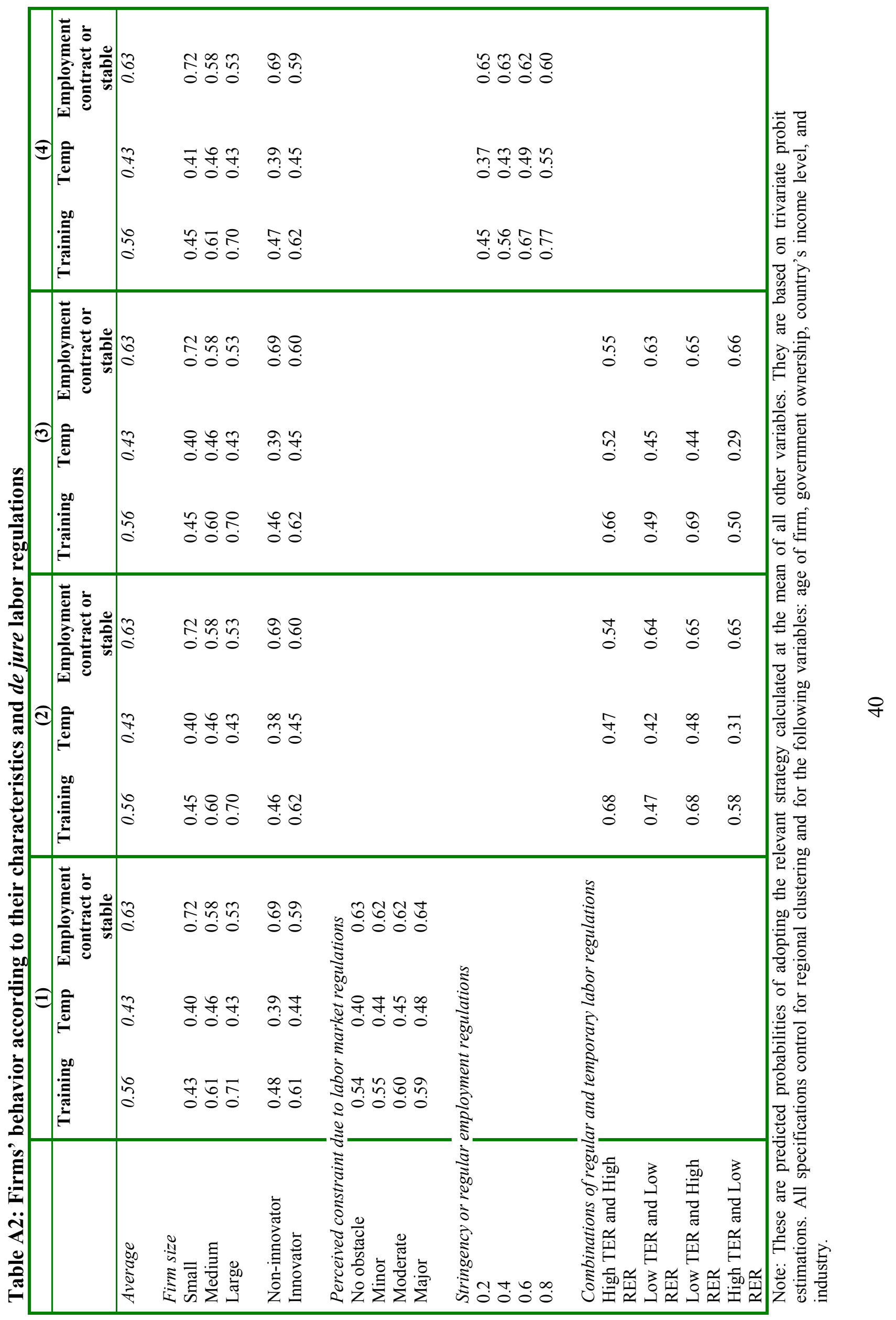


Table A3: Firms' joint behavior according to their characteristics and de jure labor regulations

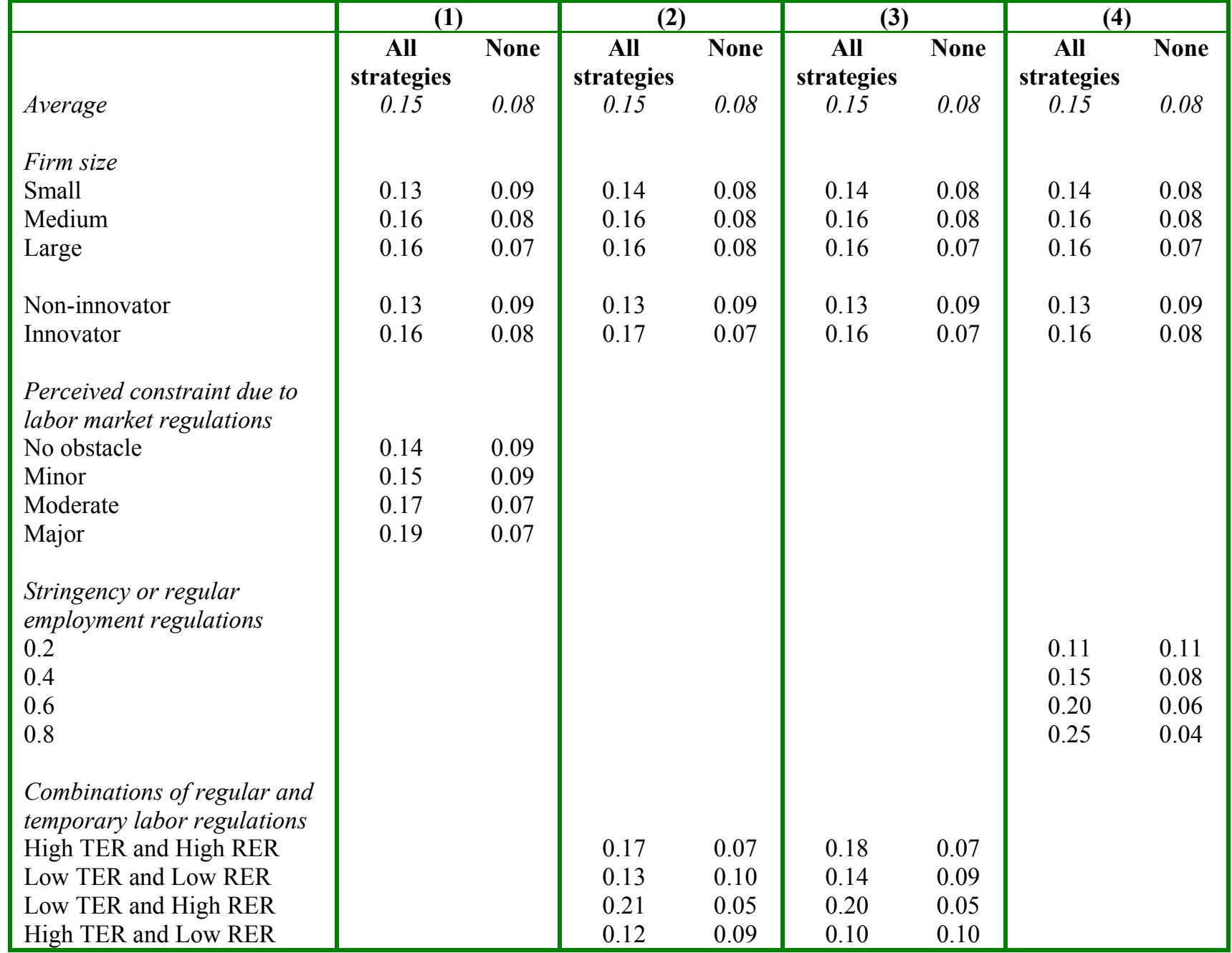

Note: These are predicted probabilities of adopting the relevant strategy calculated at the mean of all other variables. They are based on trivariate probit estimations. All specifications control for regional clustering and for the following variables: age of firm, government ownership, country's income level, and industry. 